\title{
ORACLE (v1.0): module to simulate the organic aerosol composition and evolution in the atmosphere
}

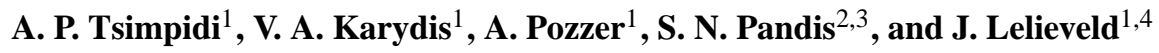 \\ ${ }^{1}$ Max Planck Institute for Chemistry, Mainz, Germany \\ ${ }^{2}$ Department of Chemical Engineering, University of Patras, Patras, Greece \\ ${ }^{3}$ Department of Chemical Engineering, Carnegie Mellon University, Pittsburgh, PA, USA \\ ${ }^{4}$ Energy, Environment and Water Research Center, Cyprus Institute, Nicosia, Cyprus \\ Correspondence to: A. P. Tsimpidi (a.tsimpidi@mpic.de)
}

Received: 13 July 2014 - Published in Geosci. Model Dev. Discuss.: 12 August 2014

Revised: 31 October 2014 - Accepted: 23 November 2014 - Published: 21 December 2014

\begin{abstract}
A computationally efficient module to describe organic aerosol (OA) partitioning and chemical aging has been developed and implemented into the EMAC atmospheric chemistry-climate model. The model simulates the formation of secondary organic aerosol (SOA) from semivolatile (SVOCs), intermediate-volatility (IVOCs), and volatile organic compounds (VOCs). It distinguishes SVOCs from biomass burning and all other combustion sources using two surrogate species for each source category with an effective saturation concentration at $298 \mathrm{~K}$ of $C^{*}=0.1$ and $10 \mu \mathrm{g} \mathrm{m}^{-3}$. Two additional surrogate species with $C^{*}=10^{3}$ and $10^{5} \mu \mathrm{g} \mathrm{m}^{-3}$ are used for the IVOCs emitted by the above source categories. Gas-phase photochemical reactions that change the volatility of the organics are taken into account. The oxidation products (SOA-sv, SOA-iv, and SOA-v) of each group of precursors (SVOCs, IVOCs, and VOCs) are simulated separately to keep track of their origin. ORACLE efficiently describes the OA composition and evolution in the atmosphere and can be used to (i) estimate the relative contributions of SOA and primary organic aerosol (POA) to total OA, (ii) determine how SOA concentrations are affected by biogenic and anthropogenic emissions, and (iii) evaluate the effects of photochemical aging and long-range transport on the OA budget. We estimate that the global average nearsurface OA concentration is $1.5 \mu \mathrm{g} \mathrm{m}^{-3}$ and consists of $7 \%$ POA from fuel combustion, $11 \%$ POA from biomass burning, $2 \%$ SOA-sv from fuel combustion, $3 \%$ SOA-sv from biomass burning, $15 \%$ SOA-iv from fuel combustion, $28 \%$ SOA-iv from biomass burning, $19 \%$ biogenic SOA-v, and
\end{abstract}

$15 \%$ anthropogenic SOA-v. The modeled tropospheric burden of OA components is $0.23 \mathrm{Tg}$ POA, 0.16 Tg SOA-sv, $1.41 \mathrm{Tg}$ SOA-iv, and 1.2 Tg SOA-v.

\section{Introduction}

Atmospheric aerosols adversely affect air quality and human health, and play an important role in climate change. Depending on the physicochemical properties, aerosols affect the energy budget of the Earth's atmosphere by scattering and absorbing solar radiation (direct effect) and influencing the reflective properties of clouds, their lifetime, and precipitation formation (indirect effects). Organic aerosol (OA) is an important constituent of atmospheric particulates and varies with geographic region, accounting for 20 to $90 \%$ of the submicron particulate mass (Zhang et al., 2007). However, the understanding of OA sources, atmospheric processing, and removal is limited. Given that anthropogenic carbonaceous emissions from developing and emerging economies are expected to dramatically increase in the future (IPCC, 2013), a better understanding of the chemical evolution of OA is essential to reduce the aerosol-related uncertainties in global climate simulations and improve air quality and climate assessments.

OA consists of primary material (POA, directly emitted from sources such as fossil fuel combustion and biomass burning) and secondary particulate matter (SOA, formed within the atmosphere from the oxidation of gas-phase pre- 
cursors). The relative contribution of POA and SOA to the overall OA budget remains controversial. Recent studies show that OA is dominated by SOA not only in tropical regions but also in urban environments (Zhang et al., 2005). The formation of SOA is often underestimated in atmospheric chemistry-climate models (CCMs) and chemistrytransport models (CTMs) (Heald et al., 2005). Robinson et al. (2007) attributed this "unexplained" SOA to the evaporation of POA, oxidation of the resulting vapors in the gas phase and subsequent recondensation, SOA formation from intermediate-volatility organic compounds (IVOCs), and chemical aging of the first-generation products of the volatile organic compounds (VOCs) that are not taken into account by models. Laboratory and field studies have confirmed that the photooxidation of fossil fuel combustion and biomass burning emissions can lead to the formation of substantial SOA mass that cannot be explained by the traditional treatment of SOA in CTMs and CCMs (Kroll and Seinfeld, 2008; Jimenez et al., 2009; Grieshop et al., 2009; Hennigan et al., 2011; Miracolo et al., 2011; May et al., 2012).

CCMs have traditionally treated POA and SOA as nonvolatile and nonreactive particles that are emitted directly into the atmosphere (Kanakidou et al., 2005). Most models convert "hydrophobic" OA to "hydrophilic" OA using an assumed aging rate constant to account for the chemical conversion of fresh OA to more water-soluble compounds and its mixing with other soluble aerosol components without any mechanistic detail. In order to describe the OA volatility changes that accompany this chemical conversion, Donahue et al. (2006) developed the volatility basis set (VBS) framework. This framework describes the OA absorptive partitioning, where OA is assumed to be semivolatile and photochemically reactive and is distributed in logarithmically spaced volatility bins. With this approach, the intermediate and semivolatile primary emissions and the SOA formation and its chemical aging can be simulated in a common framework that is well suited for regional and global modeling (Murphy and Pandis, 2009; Tsimpidi et al., 2010; Jathar et al., 2011).

Several recent regional-scale modeling studies have accounted for the semivolatile nature and chemical aging of organic compounds demonstrating improvements in reproducing the organic aerosol budget and its chemical resolution (Murphy and Pandis, 2009; Tsimpidi et al., 2010, 2011; Hodzic et al., 2010; Fountoukis et al., 2011, 2014; Shrivastava et al., 2011; Bergström et al., 2012; Athanasopoulou et al., 2013; Zhang et al., 2013). However, such efforts on a global scale are limited. Farina et al. (2010) implemented the VBS in the Goddard Institute for Space Studies General Circulation Model II' (GISS II') to describe the formation of SOA from VOCs, while assuming that POA emissions were nonvolatile and nonreactive and not accounting for IVOC emissions. Pye and Seinfeld (2010) estimated the global OA production from emissions of semivolatile organic compounds (SVOCs) and IVOCs using the global
CTM GEOS-Chem. However, this study simulated only the first generation of reactions neglecting the subsequent chemical aging. In contrast to other studies, their implementation of semivolatile POA led to decreases in modeled total surface-level OA concentrations due to the partial evaporation of POA upon emission. Jathar et al. (2011) modified the model of Farina et al. (2010) to account explicitly for the semivolatile and reactive POA and predicted a global dominance of SOA, which brought the POA/SOA fractions into better agreement with measurements. Jo et al. (2013) employed the VBS framework in the GEOS-Chem global CTM to study the effect of photochemical aging on global SOA. They found that the model results were in better agreement with all observations relative to the simulations without aging and to those of the traditional two-product approach. All of the above studies showed improved representation of POA and/or SOA in the corresponding global CTMs and brought the model predictions closer to field measurements. However, the number of studies that have employed the recent OA findings is rather limited, and in some cases these studies lack one or more potentially important processes (e.g., the aging reactions, the semivolatile character of POA).

This study aims to improve the description of organic aerosols in large-scale models, making use of the VBS approach and recent developments based on laboratory and field measurements. A new computationally efficient module for the description of organic aerosol composition and evolution in the atmosphere (ORACLE) has been developed and implemented in the ECHAM/MESSy Atmospheric Chemistry (EMAC) model (Jöckel et al., 2006) to simulate POA and SOA formation and growth. ORACLE uses a novel lumping method that allows the use of a small number of species, minimizing the computational cost. At the same time it provides valuable information about the OA sources and physicochemical evolution during its atmospheric lifetime. The ORACLE user has full control of the complexity of the OA scheme and is able to adjust the number of species and reactions, depending on the application and the desired chemical resolution (number of compounds and volatility bins), as well as the physicochemical properties of OA components (aging reaction constants, emission factors, etc.). The application of this advanced OA module can help identify gaps in our understanding of the OA formation and composition, improve the predictive capability of OA, and help in identifying the major uncertainties that should be addressed in future experimental and modeling studies.

\section{Global model description}

\subsection{EMAC model}

The ECHAM5/MESSy Atmospheric Chemistry model (EMAC) (Jöckel et al., 2006, 2010) is used as the host model for ORACLE. This is a numerical chemistry and cli- 
mate simulation system that includes submodels describing lower- and middle-atmospheric processes and their interaction with oceans, land, and human influences. EMAC combines the Modular Earth Submodel System (MESSy; Jöckel et al., 2005) and the fifth generation of the European Centre Hamburg general circulation model (ECHAM5; Röckner et al., 2006). ECHAM5 simulates the atmospheric flow with the prognostic variables vorticity, divergence, temperature, total moisture and the logarithm of the surface pressure, and is integrated in the base model layer of MESSy. The interface structure of MESSy allows the use of different modules for atmospheric chemistry, transport, and diagnostic tools. EMAC has been extensively described and evaluated against ground-based and satellite observations, and can be run with a range of spatial resolutions (Jöckel et al., 2006; Pozzer et al., 2012; de Meij et al., 2012). In this study, the applied spectral resolution is T42L31, corresponding to a horizontal grid resolution of approximately $2.8^{\circ} \times 2.8^{\circ}$ and 31 vertical layers extending to $25 \mathrm{~km}$. EMAC is applied for 6 years, covering the period 2004-2009, and the first year is used as spin-up.

The EMAC model simulates gas-phase species online through the Module Efficiently Calculating the Chemistry of the Atmosphere submodel (MECCA; Sander et al., 2011). MECCA calculates online the concentration of the major oxidants $\left(\mathrm{OH}, \mathrm{H}_{2} \mathrm{O}_{2}, \mathrm{NO}_{3}\right.$, and $\left.\mathrm{O}_{3}\right)$ by using a chemical scheme based on the MIM mechanism (Pöschl et al., 2000), including 218 gas-phase reactions, 69 photolysis reactions, and 12 heterogeneous reactions of 129 gases in total. Inorganic aerosol microphysics and gas-particle partitioning are calculated by the Global Modal-aerosol eXtension aerosol module (GMXe; Pringle et al., 2010). This submodel is computationally efficient and is suitable for medium to long-term simulations with global and regional models.

The aerosol microphysics are described using seven interacting lognormal modes (four hydrophilic and three hydrophobic modes). The four hydrophilic modes cover the full aerosol size spectrum (nucleation, Aitken, accumulation, and coarse modes). Each size range has fixed size boundaries and a variable mean radius. The three hydrophobic modes have the same size range as the hydrophilic modes apart from the nucleation mode. The aerosol composition within each mode is uniform with size (internally mixed), though the composition can vary between modes (externally mixed). The removal of gas and aerosol species through dry deposition is calculated within the DRYDEP submodel (Kerkweg et al., 2006a) based on the big-leaf approach. The sedimentation of aerosols is calculated within the SEDI submodel (Kerkweg et al., 2006a) using a first-order approach. The formation of sulfate through the aqueous-phase oxidation of $\mathrm{SO}_{2}$ is treated by the SCAV submodel (Tost et al., 2006), which calculates the aqueous-phase redox reactions based on the prognostically predicted $\mathrm{pH}$ of clouds. SCAV also simulates cloud scavenging and rainout of gas and aerosol species. The optical properties of aerosols (optical thickness, single-scattering albedo, asymmetry factor) are calculated within the AEROPT sub- model (Lauer et al., 2007) based on pre-calculated look-up tables from Mie theory. The CLOUD submodel (Jöckel et al., 2006) is used to calculate the cloud cover as well as cloud microphysics including precipitation. The detailed two-moment liquid and ice-cloud microphysical scheme of Lohmann et al. (2007), which enables a physically based treatment of aerosol-cloud interactions, is used to compute cloud microphysical processes.

\section{ORACLE description}

\subsection{Module overview}

The ORACLE module (i) uses logarithmically spaced saturation concentration bins to describe the OA components based on their volatility (Sect. 3.3), (ii) simulates the contribution of SVOCs and IVOCs from fuel combustion and biomass burning emissions and anthropogenic and biogenic VOCs to the formation of SOA (Sect. 3.4), (iii) monitors the gas-phase photochemical reactions of SOA precursors (Sect. 3.5), (iv) assumes bulk equilibrium between the gas and particulate phases (Sect. 3.6), and (v) distributes the OA in size modes (Sect. 3.6). A schematic overview of the ORACLE module and how it is implemented in EMAC is provided in Fig. 1.

\subsection{OA terminology}

The ORACLE module describes the chemical life cycle of a large number of different species involved in the formation of total atmospheric OA (i.e., 48 species are used in the current configuration) in order to cover and track the distribution of these species in multiple simultaneously occurring phases, their participation in a large number of possible formation pathways (i.e., multigenerational oxidation), their volatility distribution, and their sources. The complexity of this system demands a systematic classification of the organic compounds that will be in line with ongoing field and laboratory studies and model development. Following the Murphy et al. (2014) naming convention for classifying OA components, the ORACLE classification system has the following syntax:

[source root name] - [initial volatility],

with the "source root name" indicated by an acronym currently used in the field and the "initial volatility" of the species upon emission indicated by an alphabetical lowercase suffix. Table 1 lists the root terms and suffixes used for identifying the emitted volatility of the organic components described by ORACLE in this application. The source root name of organic components consist of lowercase alphabetical characters (Modifiers) that describe their source type (i.e., " $\mathrm{f}$ " for fuel combustion), followed by three capital letters (Base term): the first letter declares whether the 


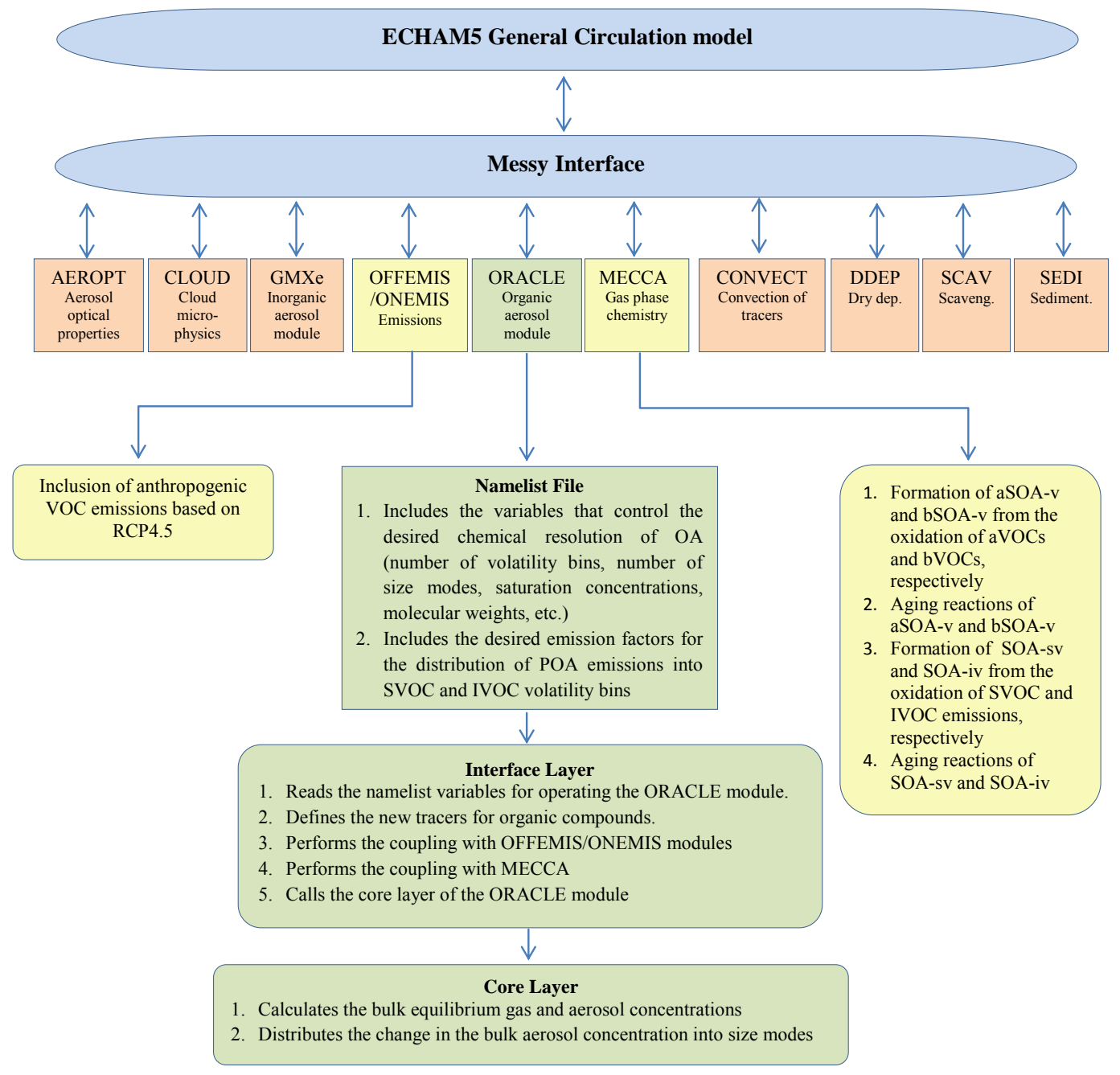

Figure 1. Diagram showing ORACLE as part of the EMAC chemistry-climate model.

organic component is primary ("P"), coming from primary emissions, or secondary ("S"), formed from the oxidation of gas-phase species; the second is always the letter "O", denoting organic; and the third identifies the phase of the species ("A" for aerosol and "G" for gas). The exact names of all the organic compounds simulated by ORACLE are listed in Table 2.

\subsection{Volatility basis set theory}

The ORACLE module adopts the volatility basis set approach proposed by Donahue et al. (2006). It subdivides the thousands of organic compounds into groups (surrogate species) with logarithmically spaced effective saturation concentrations. This framework abandons the traditional distinction between POA and SOA and allows the EMAC model to efficiently treat both semivolatile primary emissions and SOA production and then simulate the chemical evolution of these species under a unified framework. The exact volatility resolution defined and used by ORACLE can be controlled through the interface layer of the module, offering the flexibility to investigate different schemes. For the current application, eight surrogate species are used for POA divided into two groups each with saturation concentrations $C^{*}$ at $298 \mathrm{~K}$ equal to $10^{-1}, 10^{1}, 10^{3}$, and $10^{5} \mu \mathrm{g} \mathrm{m}^{-3}$ : (i) POA from biofuel combustion, fossil fuel combustion, and other urban sources (fPOA) and (ii) POA from biomass burning (bbPOA). The least volatile fraction, at $10^{-1} \mu \mathrm{g} \mathrm{m} \mathrm{m}^{-3}$, describes the low-volatility organics in the atmosphere that are mostly in the particulate phase even in remote locations. On the other hand, even under highly polluted conditions the majority of the material in the $10^{5} \mu \mathrm{g} \mathrm{m}^{-3}$ volatility bin will exist almost exclusively in the vapor phase. The user can control the complexity of the ORACLE module and can therefore easily add bins at either end of the range to describe and investigate unique conditions. It is worth mentioning that the use of low-volatility bins to accurately represent the extremely low volatility organic compounds (e.g., with $C^{*}$ 
Table 1. Organic component name classifications in the ORACLE module.

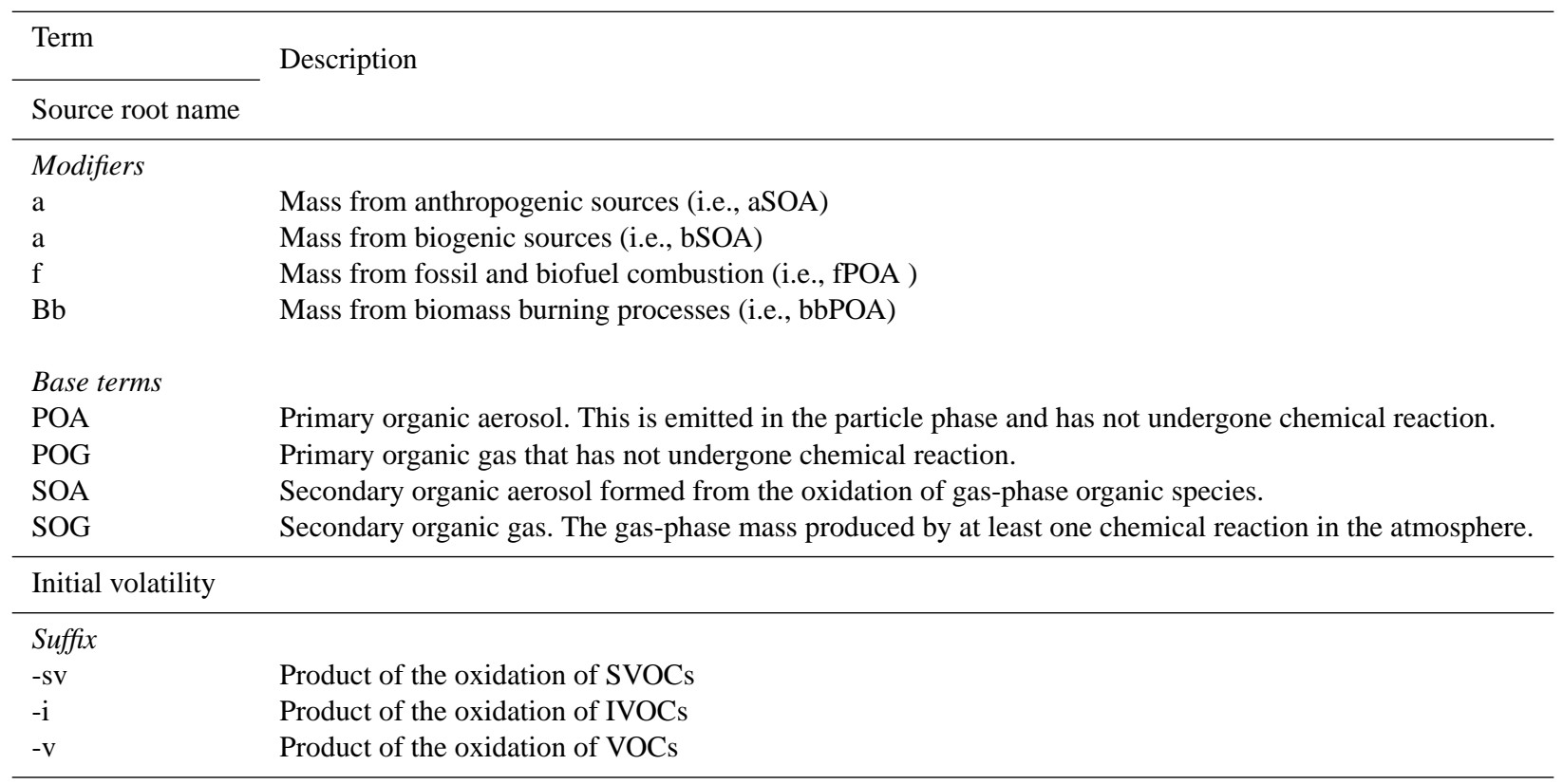

lower than $10^{-3}$ ) would be useful for the study of new particle formation, which is outside the scope of the current work and is not included in the current version of ORACLE. A similar approach is followed for SOA formed from VOCs. Following the approach of Lane et al. (2008) it is assumed that the oxidation of the anthropogenic and biogenic VOC species (aVOC and bVOC, respectively) results in four products for each precursor distributed in four volatility bins with effective saturation concentrations at $298 \mathrm{~K}$ equal to 1 , $10,10^{2}$, and $10^{3} \mu \mathrm{g} \mathrm{m}^{-3}$ at $298 \mathrm{~K}$. This range is typically constrained by available smog-chamber data (Stanier et al., 2008). A wider range can also be used and tested through the ORACLE interface. The different aerosol types and chemical processes modeled in the proposed framework are illustrated in Fig. 2.

\subsection{Emission inventory of $\mathrm{OA}$ precursors}

\section{VOC emissions}

The emissions of isoprene and monoterpenes are calculated online by EMAC with the ONLEM submodel (Kerkweg et al., 2006b) and depend on ecosystem type, temperature, and solar radiation. The AIRSEA submodel estimates the oceanic isoprene emissions from chlorophyll concentrations (Pozzer et al., 2006). In this application, isoprene and monoterpene global emissions are 477 and $62.4 \mathrm{Tg} \mathrm{yr}^{-1}$, respectively. The emissions of the aVOCs that are considered SOA precursors are derived from the CMIP5 RCP4.5 emission inventory (Clarke et al., 2007). These compounds were not considered by the original gas-phase chemistry submodel MECCA. Therefore, six lumped aVOC species have been added to
MECCA to assess the aSOA formation in ORACLE. These lumped species are grouped similarly to the Statewide Air Pollution Research Center SAPRC99 chemical mechanism (Carter, 2000) into two alkane species, two olefins, and two aromatics. The aVOCs that are considered SOA precursors and their annual global emissions are listed in Table 3.

\section{IVOC and SVOC emissions}

The EMAC model considers the contribution of fuel combustion and biomass burning to POA emissions, while primary marine organic emissions are not included in this application. The AEROCOM database is used for the aerosol emissions from fossil and biofuel combustion based on the year 2000 (Dentener et al., 2006). The biomass burning contribution is based on the Global Fire Emissions Database (GFED version 3.1), which is monthly resolved and covers the period 1997-2009 (van der Werf et al., 2010). These emission data sets treat POA as nonreactive and nonvolatile. However, the POA concentration upon emission is highly sensitive to ambient conditions, including dilution and temperature (Hildemann et al., 1989; Lipsky and Robinson, 2006). ORACLE accounts for the volatility of POA emissions by distributing the traditional nonvolatile emissions into emissions of SVOCs and IVOCs. SVOCs have saturation concentrations between 0.01 and $100 \mu \mathrm{g} \mathrm{m}^{-3}$ and exist in both the gas and particulate phases under typical ambient conditions. IVOCs have saturation concentrations between $10^{3}$ and $10^{6} \mu \mathrm{g} \mathrm{m}^{-3}$ and exist in the gas phase (Pandis et al., 2013).

For the current application, the model distinguishes SVOCs from biomass burning and other combustion sources (biofuel and fossil fuel combustion, and other urban sources) 


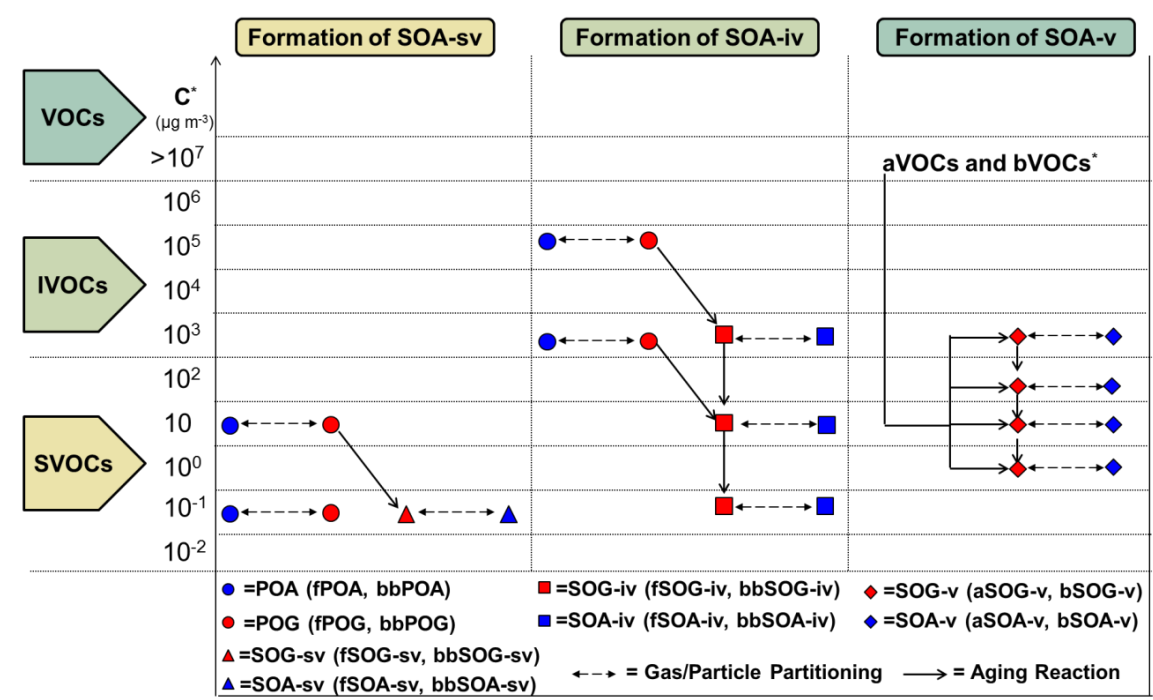

Figure 2. Schematic of the VBS resolution and the formation procedure of SOA from SVOC, IVOC, and VOC emissions. Red indicates that the compound is in the vapor phase and blue in the particulate phase. The circles correspond to primary organic material that can be emitted either in the gas or in the aerosol phase. The triangles indicate the formation of SOA from SVOCs by fuel combustion and biomass burning sources, while the squares show SOA from IVOCs by fuel combustion and biomass burning sources, and the diamonds the formation of SOA from anthropogenic and biogenic VOC sources. The partitioning processes, the aging reactions, and the names of the species used to track all compounds are also shown. * For this application it is assumed that SOA formed by biogenic VOCs does not participate in aging reactions (Lane et al., 2008; Tsimpidi et al., 2010).

Table 2. Description of ORACLE organic compounds in gas and aerosol phases.

\begin{tabular}{lll}
\hline Gas-phase compounds & Particle-phase compounds & Description \\
\hline fPOG & fPOA & Primary organic compounds from fuel combustion \\
bbPOG & bbPOA & Primary organic compounds from biomass burning \\
fSOG-sv & fSOA-sv & Secondary organic compounds from the oxidation of fuel combustion SVOCs \\
bbSOG-sv & bbSOA-sv & Secondary organic compounds from the oxidation of biomass burning SVOCs \\
fSOG-iv & fSOA-iv & Secondary organic compounds from the oxidation of fuel combustion IVOCs \\
bbSOG-iv & bbSOA-iv & Secondary organic compounds from the oxidation of biomass burning IVOCs \\
aSOG-v & aSOA-v & Secondary organic compounds from the oxidation of anthropogenic VOCs \\
bSOG-v & bSOA-v & Secondary organic compounds from the oxidation of biogenic VOCs \\
\hline
\end{tabular}

using two surrogate species for each emission category with effective saturation concentration at $298 \mathrm{~K}$ of $C^{*}=0.1$ and $10 \mu \mathrm{g} \mathrm{m}^{-3}$ to cover the volatility range of SVOCs $(0.01$ to $\left.100 \mu \mathrm{g} \mathrm{m}^{-3}\right)$. For the IVOCs, two additional surrogate species with $C^{*}=10^{3}$ and $10^{5} \mu \mathrm{g} \mathrm{m}^{-3}$ are used for each of the above two source categories to cover the corresponding volatility range $\left(10^{3}\right.$ to $\left.10^{6} \mu \mathrm{g} \mathrm{m}^{-3}\right)$. The emission factors used for the distribution of traditional POA emissions into SVOCs and IVOCs are based on the work of Tsimpidi et al. (2010). These emission factors also account for the additional IVOC emissions that were not included in the original emission inventory used by EMAC. Traditional emission inventories account only for a small fraction of the IVOCs since they are based on samples using quartz and/or Teflon filters collected at aerosol concentrations up to $10^{4} \mu \mathrm{g} \mathrm{m}^{-3}$ (Shrivastava et al., 2008; Robinson et al., 2010). The amount of IVOC emissions missing from traditional inventories is estimated to be between 0.25 and 2.8 times the traditional POA emissions (Schauer et al., 1999, 2001, 2002). In this study, we assume that the missing IVOC emissions are 1.5 times the traditional emission inventory (Shrivastava et al., 2008; Tsimpidi et al., 2010) and are assigned to the fourth volatility bin with $C^{*}=10^{5} \mu \mathrm{g} \mathrm{m}^{-3}$. Table 4 lists the emission factors for each SVOC and IVOC and their total annual global emissions from fuel combustion use and biomass burning. SVOCs are assumed to be emitted as POA, while IVOCs are emitted as POG. Thus, they are allowed to partition between the gas and particle phase, which can result in some POG from the evaporation of POA. 
Table 3. Global annual emissions of the lumped anthropogenic VOC species introduced in the ORACLE module.

\begin{tabular}{llr}
\hline VOC lumped species & RCP4.5 species & $\begin{array}{r}\text { Emission rates } \\
\left(\mathrm{Tg} \mathrm{yr}^{-1}\right)\end{array}$ \\
\hline ARO1 & Benzene, toluene & 18.3 \\
ARO2 & Trimethyl benzenes, xylene, other aromatics & 13.9 \\
ALK4 & Pentanes & 15.1 \\
ALK5 & Hexanes, other higher alkenes & 21.2 \\
OLE1 & Propene & 7.4 \\
OLE2 & Other alkenes & 8.2 \\
\hline
\end{tabular}

Table 4. Emission factors of the primary organic compounds from fuel combustion and biomass burning sources for each volatility bin used in ORACLE. The total global annual emission rates are also shown. The SVOC/IVOC emission rates are estimated by multiplying the emission factors of each bin by the nonvolatile emissions rates.

\begin{tabular}{|c|c|c|c|c|c|c|c|}
\hline \multicolumn{5}{|c|}{ Volatility distribution } & $\begin{array}{l}\text { Non Volatile } \\
\text { POA } \\
\text { emission rates } \\
\text { Tg yr }^{-1}\end{array}$ & \multirow{2}{*}{$\begin{array}{l}\text { SVOC } \\
\text { emission rates } \\
\mathrm{Tg} \mathrm{yr}^{-1}\end{array}$} & \multirow{2}{*}{$\begin{array}{l}\text { IVOC } \\
\text { emission rates } \\
\mathrm{Tg} \mathrm{yr}^{-1}\end{array}$} \\
\hline$C^{*}\left(\mu \mathrm{g} \mathrm{m}^{-3}\right)$ at $298 \mathrm{~K}$ & $10^{-1}$ & $10^{1}$ & $10^{3}$ & $10^{5}$ & & & \\
\hline Fuel combustion OA & fPOA1 & fPOA2 & fPOG3 & fPOG4 & 12.3 & 6.2 & 24.6 \\
\hline Biomass burning OA & bPOA1 & bbPOA2 & bbPOG3 & bbPOG4 & 24.8 & 12.4 & 49.6 \\
\hline Emission factors & 0.18 & 0.32 & 0.5 & 1.5 & & & \\
\hline
\end{tabular}

\subsection{Photochemical reactions}

\section{Photooxidation of VOCs}

The photochemical oxidation of VOCs that are considered as SOA precursors has been implemented into MECCA. The updated mechanism considers the oxidation of alkenes, aromatics and isoprene by $\mathrm{OH}$, and the oxidation of olefins and monoterpenes by $\mathrm{O}_{3}, \mathrm{O}, \mathrm{OH}$, and $\mathrm{NO}_{3}$. The oxidation products from anthropogenic (alkenes, aromatics, and olefins) and biogenic (monoterpenes and isoprene) VOCs are lumped into two groups: (1) secondary organic aerosols from the oxidation of anthropogenic VOCs (aSOA-v), and (2) secondary organic aerosols from the oxidation of biogenic VOCs (bSOA-v). These groups are further distributed into volatility bins with logarithmically spaced effective saturation concentrations (Fig. 2). The photooxidation of aVOCs and bVOCs is described by the following reactions:

$$
\begin{array}{r}
\mathrm{aVOC}+\text { Oxidants } \rightarrow \sum_{i=1}^{n} a_{i} \mathrm{aSOG}-\mathrm{v}_{i}, \\
\mathrm{aSOG}-\mathrm{v}_{i} \leftrightarrow \mathrm{aSOA}-\mathrm{v}_{i}, \\
\mathrm{bVOC}+\text { Oxidants } \rightarrow \sum_{i=1}^{n} a_{i} \mathrm{bSOG}-\mathrm{v}_{i}, \\
\mathrm{bSOG}-\mathrm{v}_{i} \leftrightarrow \mathrm{bSOA}-\mathrm{v}_{i},
\end{array}
$$

where $a_{i}$ is the aerosol yield, $i$ is the corresponding volatility bin, and $n$ is the total number of volatility bins. In this application, four volatility bins are considered and the correspond-
Table 5. Secondary organic aerosol mass yield* parameters.

\begin{tabular}{lrrrr}
\hline & \multicolumn{4}{c}{$C^{*}$ in $\mu \mathrm{g} \mathrm{m}^{-3}$ at $298 \mathrm{~K}$} \\
\cline { 2 - 5 } VOC lumped species & 1 & 10 & $10^{2}$ & $10^{3}$ \\
\hline ARO1 & 0.003 & 0.165 & 0.300 & 0.435 \\
ARO2 & 0.002 & 0.195 & 0.300 & 0.435 \\
ALK4 & 0.000 & 0.038 & 0.000 & 0.000 \\
ALK5 & 0.000 & 0.150 & 0.000 & 0.000 \\
OLE1 & 0.001 & 0.005 & 0.038 & 0.150 \\
OLE2 & 0.003 & 0.026 & 0.083 & 0.270 \\
ISOP & 0.009 & 0.030 & 0.015 & 0.000 \\
TERP & 0.107 & 0.092 & 0.359 & 0.600 \\
\hline
\end{tabular}

* The SOA yields are based on an assumed particle density of $1.5 \mathrm{~g} \mathrm{~cm}^{-3}$.

ing aerosol yields are those used by Tsimpidi et al. (2010) based on laboratory results from smog-chamber experiments under high- $\mathrm{NO}_{\mathrm{x}}$ conditions for aVOCs and low- $\mathrm{NO}_{\mathrm{x}}$ conditions for bVOCs (Table 5). This is based on the assumption that urban areas, where most of aVOCs are emitted ( 90\%), are characterized by high- $\mathrm{NO}_{\mathrm{x}}$ conditions (Tsimpidi et al., 2008; Karl et al., 2009) and forested regions by low- $\mathrm{NO}_{\mathrm{x}}$ conditions (Pugh et al., 2010; Browne et al., 2013).

\section{Chemical aging reactions}

ORACLE treats all OA compounds as chemically reactive. However, only homogeneous gas-phase aging is considered since it is rapid compared to heterogeneous reactions with 
Table 6. Statistical evaluation of monthly averaged modeled OA against IMPROVE, EMEP, and East Asia observations during $2005-2009$.

\begin{tabular}{lrrrrrrrr}
\hline Network & $\begin{array}{r}\text { Number of } \\
\text { stations }\end{array}$ & $\begin{array}{r}\text { Mean observed } \\
\left(\mu \mathrm{g} \mathrm{m}^{-3}\right)\end{array}$ & $\begin{array}{r}\text { Mean modeled } \\
\left(\mu \mathrm{g} \mathrm{m}^{-3}\right)\end{array}$ & $\begin{array}{r}\text { MAGE } \\
\left(\mu \mathrm{g} \mathrm{m}^{-3}\right)\end{array}$ & $\begin{array}{r}\text { MB } \\
\left(\mu \mathrm{g} \mathrm{m}^{-3}\right)\end{array}$ & $\begin{array}{r}\text { NME } \\
(\%)\end{array}$ & $\begin{array}{r}\text { NMB } \\
(\%)\end{array}$ & $\begin{array}{r}\text { RMSE } \\
\left(\mu \mathrm{g} \mathrm{m}^{-3}\right)\end{array}$ \\
\hline IMPROVE & $193^{\mathrm{a}}$ & 1.93 & 3.02 & 1.71 & 1.09 & 89 & 57 & 2.6 \\
EMEP & $10^{\mathrm{b}}$ & 1.81 & 2.20 & 1.21 & 0.39 & 67 & 22 & 2.09 \\
East Asia & $18^{\mathrm{c}}$ & 11.02 & 7.09 & 4.76 & -3.93 & 43 & -36 & 5.53 \\
\hline
\end{tabular}

a 10202 measurements. ${ }^{b} 301$ measurements. ${ }^{c} 74$ measurements.

OH (Donahue et al., 2013). Smog-chamber results indicate a net average decrease in volatility (and increase in SOA production) of aSOA-v after multigenerational aging (Hildebrandt et al., 2009). In this application, the volatilities of aSOA-v reacting with $\mathrm{OH}$ are reduced by a factor of 10 (Fig. 2) with a rate constant of $1 \times 10^{-11} \mathrm{~cm}^{3}$ molecule ${ }^{-1} \mathrm{~s}^{-1}$ (Tsimpidi et al., 2010) and a $7.5 \%$ increase in mass to account for one added oxygen, assuming a $\mathrm{C}_{15}$ precursor. aSOA-v can participate in up to three generations of oxidation, reaching a final organic matter / organic carbon ratio (OM / OC) up to 2.2 (assuming an initial OM / OC of $1.8)$, which is within the limits (OM / OC: $1.8-2.4)$ of the observed OM / OC of the oxygenated organic aerosols (Aiken et al., 2008). Existing evidence suggests that the aging of bSOA-v does not result in an important change in its mass concentration (Ng et al., 2006; Donahue et al., 2012). Murphy et al. (2012) attributed this to a balancing of fragmentation and functionalization effects during the photochemical aging of bSOA-v. Therefore, it is assumed here that the chemical aging of bSOA-v does not result in a net increase of the corresponding SOA concentration. The chemical aging of aSOA-v is described by the following reaction:

$$
\begin{array}{r}
\mathrm{aSOG}-\mathrm{v}_{i}+\mathrm{OH} \rightarrow 1.075 \mathrm{aSOG}-\mathrm{v}_{i-1}, \\
\mathrm{aSOG}-\mathrm{v}_{i-1} \leftrightarrow \mathrm{aSOA}-\mathrm{v}_{i-1} .
\end{array}
$$

The volatilities of SVOCs and IVOCs are reduced by a factor of 100 (Fig. 2) as a result of the $\mathrm{OH}$ reaction with a rate constant of $2 \times 10^{-11} \mathrm{~cm}^{3}$ molecule ${ }^{-1} \mathrm{~s}^{-1}$ (Pye and Seinfeld, 2010) and a $15 \%$ increase in mass to account for two added oxygens, assuming a $\mathrm{C}_{15}$ precursor. This represents a more aggressive addition of oxygen and reduction in volatility compared to aSOA-v. In the present application, SVOCs and IVOCs can participate in up to three generations of oxidation, reaching a final OM / OC up to 1.8 (assuming an initial $\mathrm{OM} / \mathrm{OC}$ of 1.2), which is consistent with the observed OM / OC (OM / OC : 1.8-2.4) of the oxygenated organic aerosols (Aiken et al., 2008). The oxidation products of SVOCs and IVOCs are called SOA from the oxidation of fuel combustion and biomass burning SVOCs (fSOA-sv and bbSOA-sv, respectively) and SOA from the oxidation of fuel combustion and biomass burning IVOCs (fSOA-iv and bbSOA-iv, respectively). The photooxidation of SVOCs and
IVOCs is described by the following reactions:

$$
\begin{aligned}
& \mathrm{fSVOC}_{i}+\mathrm{OH} \rightarrow 1.15 \mathrm{fSOG}-\mathrm{sv}_{i-1}, \\
& \mathrm{fSOG}-\mathrm{sv}_{i-1} \leftrightarrow \mathrm{fSOA}-\mathrm{sv}_{i-1} \text {, } \\
& \mathrm{fIVOC}_{i}+\mathrm{OH} \rightarrow 1.15 \mathrm{fSOG}_{-1 \mathrm{iv}}{ }_{i-1}, \\
& \text { fSOG-iv } v_{i-1} \leftrightarrow \mathrm{fSOA}-\mathrm{iv}_{i-1} \text {, } \\
& \mathrm{bbSVOC}_{i}+\mathrm{OH} \rightarrow 1.15 \mathrm{bbSOG}-\mathrm{sv}_{i-1}, \\
& \text { bbSOG }-\mathrm{sv}_{i-1} \leftrightarrow \text { bbSOA }-\mathrm{sv}_{i-1} \text {, } \\
& \mathrm{bbIVOC}_{i}+\mathrm{OH} \rightarrow 1.15 \mathrm{bbSOG}-\mathrm{iv}_{i-1},
\end{aligned}
$$

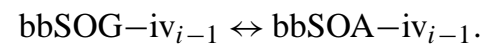

The products of Reactions (R7)-(R14) can be further oxidized by $\mathrm{OH}$-forming species with lower saturation concentration until they reach the lowest volatility bin (i.e., the oxidation of fSOA-sv $i$ will produce the fSOA-sv $i-1$ ). Overall, all OA surrogate species are assumed to have a constant hygroscopicity parameter kappa of 0.14 that remains constant during their atmospheric aging.

\subsection{Gas-aerosol partitioning}

ORACLE calculates the partitioning of organic compounds between the gas and particle phases by assuming bulk equilibrium and that all organic compounds form a pseudo-ideal solution. The gas-aerosol partitioning is performed in two steps as follows.

\section{Bulk equilibrium}

ORACLE calculates the bulk equilibrium gas and aerosol concentrations following the approach of the SOAM II model of Strader et al. (1999). Considering partitioning of $n$ organic compounds and assuming pseudo-ideal solution, a set of $n$ nonlinear equations is obtained:

$$
\begin{aligned}
c_{\mathrm{a}, i} & =c_{\mathrm{t}, i}-x_{i} c_{i}^{*} \text { for } i=1, n \\
x_{i} & =\frac{c_{\mathrm{a}, i} / M_{i}}{\sum_{j=1}^{n} c_{\mathrm{a}, j} / M_{j}}
\end{aligned}
$$

where $c_{\mathrm{t}, i}$ and $c_{\mathrm{a}, i}$ are the total and aerosol-phase concentrations of product $i$ in $\mu \mathrm{g} \mathrm{m}^{-3}$, respectively; $c_{i}^{*}$ is the effective saturation concentration of product $i ; x_{i}$ is the mole fraction of product $i$ in the absorbing organic phase; and $M_{i}$ 
is the molecular weight of product $i$. The molecular weights of all POA, SOA-sv, and SOA-iv components are assumed to be $250 \mathrm{~g} \mathrm{~mol}^{-1}$, while the molecular weights of bSOA-v and aSOA-v are 180 and $150 \mathrm{~g} \mathrm{~mol}^{-1}$, respectively (Tsimpidi et al., 2010). The temperature dependence of saturation concentrations is described by the Clausius-Clapeyron equation:

$c_{i}^{*}=c_{i, 0}^{*} \frac{T_{0}}{T} \exp \left[\frac{\Delta H}{R}\left(\frac{1}{T_{0}}-\frac{1}{T}\right)\right]$,

where $c_{i}^{*}$ and $c_{i, 0}^{*}$ are the saturation concentrations at temperature $T$ and $T_{0}$, respectively; $R$ is the gas constant; and $\Delta H$ is the enthalpy of vaporization. In this application an effective $\Delta H$ of $30 \mathrm{~kJ} \mathrm{~mol}^{-1}$ is used for all aSOA-v and bSOA-v species based on data for $\alpha$-pinene (Pathak et al., 2007), and a $\Delta \mathrm{H}$ of $106,94,82$, and $70 \mathrm{~kJ} \mathrm{~mol}^{-1}$ is used for the $10^{-1}$, $10^{1}, 10^{3}, 10^{5} \mu \mathrm{g} \mathrm{m}^{-3}$ volatility bins, respectively, for all organic compounds from fuel combustion and biomass burning sources based on data for large saturated species commonly found in primary emissions (Donahue et al., 2006). ORACLE solves this equation set, which yields the bulk aerosol composition at equilibrium.

\section{Aerosol size distribution}

The aerosol size distribution is determined by distributing the change in aerosol mass after the bulk equilibrium into each size mode using a weighting factor (Pandis et al., 1993). Assuming pseudo-ideal solution, the fraction, $f_{i, k}$, of total flux of species $i$ between gas and aerosol phases that condenses onto or evaporates from an aerosol mode $k$ is given by

$$
f_{i, k}=\frac{N_{k} d_{k}\left(c_{i}-x_{i, k} c_{i}^{*}\right) /\left(\beta_{k}+1\right)}{\sum_{l=1}^{m} N_{l} d_{l}\left(c_{i}-x_{i, l} c_{i}^{*}\right) /\left(\beta_{l}+1\right)}
$$

where $N_{k}$ and $d_{k}$ are the number and mean diameter of particles in the mode $k$, respectively; $m$ is the total number of aerosol modes; $\beta_{k}=2 \lambda / \alpha d_{k} ; \alpha$ is the aerosol accommodation coefficient; and $\lambda$ is the mean free path of air molecules (Pandis et al., 1993). The above equation is solved iteratively at each time step and determines the OA composition of each mode. Overall, the user is allowed to use up to three hydrophilic modes (Aitken, accumulation, coarse) for the size distribution of all OA surrogate species. In the current application, only the accumulation mode is used to limit the computational cost of the module.

\section{Model results}

\subsection{Total OA concentrations}

The model calculated global average surface OA concentration is $1.5 \mu \mathrm{g} \mathrm{m}^{-3}$ (Fig. 3). High OA concentrations are modeled over regions affected by biomass burning and biogenic VOC emissions: the tropical forests and savannas of South

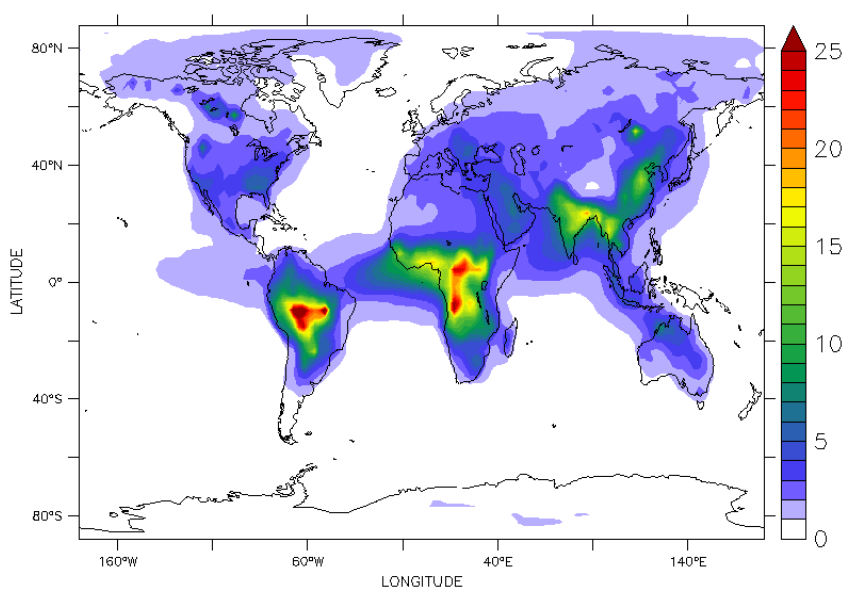

Figure 3. Modeled average surface concentration of total OA $\left(\mu \mathrm{g} \mathrm{m}^{-3}\right)$ during the years 2005-2009.

America (Amazon Basin), Africa (Congo Basin), and Southeast Asia. These areas are characterized by a pronounced annual cycle due to the influence of two distinct seasons, the wet and dry periods. The dry season is characterized by intense wildfires and OA consists mainly of biomass burning OA. The wet season is characterized by low biomass burning emissions; therefore, OA consists mainly of biogenic SOA. Considerable OA concentrations are also calculated over the industrialized regions of the Northern Hemisphere (i.e., China, Europe, and the eastern USA), where strong fossil-fuel- and biofuel-combustion-related sources are located. The model simulates a continental background OA concentration of $1-2 \mu \mathrm{g} \mathrm{m}^{-3}$, which is mainly formed by the condensation of oxidized low-volatility organic gases. These gases are formed from the photochemical aging of VOCs, IVOCs, and SVOCs which have been emitted in the gas phase and have been efficiently transported remote from their sources. The effects of trade wind transport of bbOA off the subtropical west coasts of Africa and America are discernible in Fig. 3. In these regions, the OA concentration is increased by long-range transport of continental air masses to adjacent ocean areas.

\subsection{Model performance evaluation}

Figure 4 shows the comparison of model calculated OA concentrations with measurements from the European Monitoring and Evaluation Programme (EMEP; http://nilu.no/projects/ccc/onlinedata/pm/) and the Interagency Monitoring of protected Visual Environments (IMPROVE; http://vista.cira.colostate.edu/improve/Data/ IMPROVE/improve_data.htm), as well as short-term measurement data collected over East Asia as summarized by Jo et al. (2013). Each point of the scatterplots represents a monthly average value at a particular monitoring station. The mean bias (MB), mean absolute gross error (MAGE), 

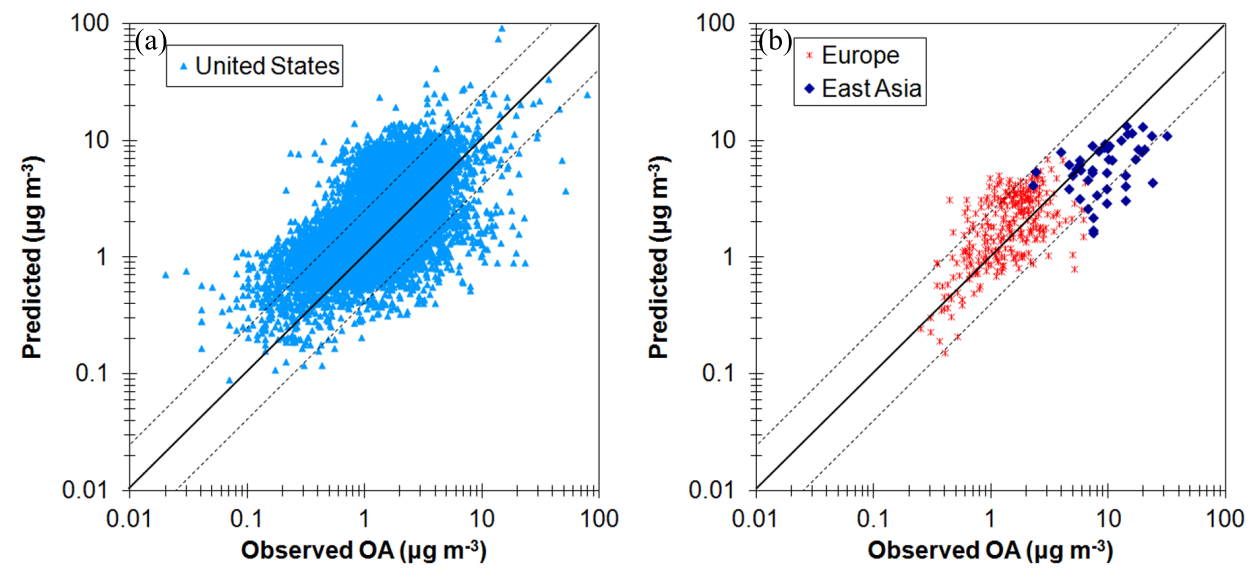

Figure 4. Scatterplot comparing model predictions of total OA concentration (in $\mu \mathrm{g} \mathrm{m}^{-3}$ ) with observations from the (a) IMPROVE network in the United States. (b) EMEP network in Europe and East Asian sites from 2005 to 2009. Each point represents a monthly average value. Also shown are the $1: 1,2: 1$, and $1: 2$ lines.

normalized mean bias (NMB), normalized mean error (NME), and the root-mean-square error (RMSE) were also calculated (Table 6) to assess the model performance:

$$
\begin{aligned}
\text { MAGE } & =\frac{1}{N} \sum_{i=1}^{N}\left|P_{i}-O_{i}\right| \quad \mathrm{MB}=\frac{1}{N} \sum_{i=1}^{N}\left(P_{i}-O_{i}\right) \\
\mathrm{NME} & =\frac{\sum_{i=1}^{N}\left|P_{i}-O_{i}\right|}{\sum_{i=1}^{N} O_{i}} \quad \mathrm{NMB}=\frac{\sum_{i=1}^{N}\left(P_{i}-O_{i}\right)}{\sum_{i=1}^{N} O_{i}} \\
\mathrm{RMSE} & =\left[\frac{1}{N} \sum_{i=1}^{N}\left(P_{i}-O_{i}\right)^{2}\right]^{\frac{1}{2}},
\end{aligned}
$$

where $P_{i}$ is the modeled OA mass, $O_{i}$ is the observed value of OA at the same monthly averaged time, and $N$ is the total number of data points used for the comparison. NME (in \%) and MAGE (in $\mu \mathrm{g} \mathrm{m}^{-3}$ ) provide an assessment of the overall discrepancy between model predictions and observations, while NMB (in \%) and MB (in $\mu \mathrm{g} \mathrm{m}^{-3}$ ) are indicative of systematic errors. RMSE (in $\mu \mathrm{g} \mathrm{m}^{-3}$ ) incorporates both the variance of the prediction and its bias. Both NME and MAGE inherently include the corresponding bias, which is the reason why their magnitude is equal or larger than NMB and MB, respectively. For an unbiased calculation, NME and MAGE express the variance. When NME and NMB or MAGE and $\mathrm{MB}$, respectively, are close to each other in magnitude, the discrepancy is explained as a systematic bias rather than scatter. When the magnitude of NME/MAGE is larger than $\mathrm{NMB} / \mathrm{MB}$, part of the discrepancy between predictions and observations is explained as scatter.

The model, despite its coarse resolution, captures the monthly average concentrations of OA relatively well over the USA, Europe, and Asia (Table 6). This is rather encouraging given the expected uncertainties in the emission in- ventory and in a number of parameters used by the model such as the emission fractions for POA from fuel combustion and biomass burning, the reaction rates and aerosol yields that accompany the formation of SOA from SVOCs, IVOCs, VOCs, etc. In addition, the fact that the formation of SOA from aqueous-phase reactions and heterogeneous reactions, including processes like oligomerization, has not been accounted for, adds to the model bias. However, despite these limitations, the modeled total OA concentrations are generally in reasonable agreement with the measurements. More precisely, over the USA, the model overestimates the OA with a NMB of $57 \%$. The high NME (89\%) indicates that part of the discrepancy between model results and observations is explained as scatter, which is visible in Fig. 4a. Over Europe, the model overestimates OA with a NMB of $22 \%$. The measurements of OA at the station of Ispra, Italy, are systematically high (up to $22 \mu \mathrm{g} \mathrm{m}^{-3}$ ) and have been excluded from the statistical analysis. The model performs worst over East Asia (RMSE $=5.5$ ) and underestimates OA concentrations with a NMB of $-36 \%$ since it cannot capture the high values measured over Beijing and Shijiazhuang (up to $32 \mu \mathrm{g} \mathrm{m}^{-3}$ ), possibly due to its limited spatial resolution.

In contrast to highly populated areas, long-term observations of OA over forests are unavailable; therefore we have collected OA data measured during the short-term field campaigns of DABEX, DODO, and AMMA over subtropical West Africa (Capes et al., 2008, 2009); AMAZE-08 and SAMBBA over the Amazon rainforest (Chen et al., 2009; Brito et al., 2014); and measurement data collected over the Canadian boreal forest (Schwartz et al., 2010; Takahama et al., 2011). Capes et al. (2008) performed aircraft measurements during the DABEX and DODO field experiments (January and February of 2006) over subtropical West Africa at altitudes up to $4000 \mathrm{~m}$. This period was characterized by intense agricultural fires in the sub-Sahelian part of West Africa resulting in high OA concentrations $\left(4-16 \mu \mathrm{g} \mathrm{m}^{-3}\right)$. EMAC 
agrees reasonably well with the observations since the calculated OA concentrations during January and February of 2006 range between 2 and $12.5 \mu \mathrm{g} \mathrm{m}^{-3}$, mainly due to high biomass burning emissions over the area. During the wet season of the same year (July and August 2006), Capes et al. (2009) carried out aircraft measurements over subtropical West Africa in the frame of the AMMA project. This period is characterized by low biomass burning emissions; therefore, OA consists according to EMAC mainly of biogenic SOA. The observed median concentration is $1.1 \mu \mathrm{g} \mathrm{m}^{-3}$ while EMAC calculates an average value of $2.7 \mu \mathrm{g} \mathrm{m}^{-3}$. In the northwestern Amazon Basin, Chen et al. (2009) reported OA concentrations of 0.6 and $0.9 \mu \mathrm{g} \mathrm{m}^{-3}$ on average during the wet season of 2008 (February and March) as part of the AMAZE-08 experiment. The corresponding average OA concentration by EMAC is $2.7 \mu \mathrm{g} \mathrm{m}^{-3}$. During the dry season (September 2012), Brito et al. (2014) reported an average OA concentration of $13.7 \mu \mathrm{g} \mathrm{m}^{-3}$ in the southwestern Amazon Basin during the SAMBBA field experiment. Since this value is mostly affected by biomass burning emissions (which vary significantly interannually) and the EMAC model applied emissions during the years 2005-2009, a direct comparison between observations and measurements is not possible. However, EMAC captures the increased concentrations during the dry seasons since $\mathrm{OA}$ varies between 9.8 and $30 \mu \mathrm{g} \mathrm{m}^{-3}$ over the same area during the months of September. Finally, Schwartz et al. (2010) and Takahama et al. (2011) performed measurements of OA over the boreal forest of British Columbia, Canada, during May-June 2008 and March-September 2009, respectively. The reported values were $1.3 \mu \mathrm{g} \mathrm{m}^{-3}$ (May-June 2008), $0.6 \mu \mathrm{g} \mathrm{m}^{-3}$ (MarchApril 2009), and $4.1 \mu \mathrm{g} \mathrm{m}^{-3}$ (May-September 2009). The OA concentrations calculated by EMAC fit well with this range of observations with values of 1.4, 0.9, and $4.5 \mu \mathrm{g} \mathrm{m}^{-3}$, respectively.

\subsection{Primary organic aerosol}

POA is the fraction of the organic emissions that is emitted and contained in the aerosol phase and has not undergone chemical reactions. POA in the present application is divided into PPOA and bbPOA depending on its source as described in Sect. 3.3. fPOA and bbPOA have high concentrations close to their sources; further downwind the concentrations rapidly decrease due to dilution and evaporation (Fig. 5).

\section{fPOA}

The global and land average surface concentrations of fPOA are 0.11 and $0.22 \mu \mathrm{g} \mathrm{m}^{-3}$, respectively (Table 7, Fig. 5a). Fossil fuels and biofuels are used in the industrial, residential, and transport sectors; therefore the fPOA concentration peaks over densely populated and highly industrialized areas. In fact, the highest fPOA concentration is calculated over eastern China (up to $8 \mu \mathrm{g} \mathrm{m}^{-3}$ over Beijing), India and
Bangladesh (1-4 $\left.\mu \mathrm{g} \mathrm{m}^{-3}\right)$. In Europe the highest concentration is found over eastern European countries $\left(1-2 \mu \mathrm{g} \mathrm{m}^{-3}\right.$ over Poland and Romania), central Europe $\left(0.5-1 \mu \mathrm{g} \mathrm{m}^{-3}\right.$ over the greater Paris and Rhine-Ruhr areas), and in the vicinity of Moscow $\left(0.5-1 \mu \mathrm{g} \mathrm{m}^{-3}\right)$. Over Africa, fPOA concentrations peak over the western part of the continent (1$3 \mu \mathrm{g} \mathrm{m}^{-3}$ over Nigeria), while it is also high over the greater areas of Addis Ababa, Kampala, and Johannesburg (0.5$1.5 \mathrm{\mu g} \mathrm{m}^{-3}$ ). Over North America, the highest fPOA levels are modeled around Los Angeles $\left(0.5-1 \mu \mathrm{g} \mathrm{m}^{-3}\right)$, the northeastern USA $\left(0.5-1.5 \mu \mathrm{g} \mathrm{m}^{-3}\right)$, and the Mexico City metropolitan area $\left(0.5-1 \mu \mathrm{g} \mathrm{m}^{-3}\right)$, while over South America fPOA is high over the greater area of Rio de Janeiro (0.5$\left.1 \mu \mathrm{g} \mathrm{m}^{-3}\right)$.

\section{bbPOA}

The global and land average surface concentrations of bbPOA are 0.12 and $0.39 \mu \mathrm{g} \mathrm{m}^{-3}$, respectively (Table 7, Fig. 5b). The bbPOA levels are affected by emissions from forest, woodland, peatland, and savanna fires as well as agricultural waste burning. Therefore, high concentrations are modeled over the tropical rainforest and savannas in the Amazon and Congo basins $\left(5-10 \mu \mathrm{g} \mathrm{m}^{-3}\right)$, Southeast Asia (3-6 $\mu \mathrm{g} \mathrm{m}^{-3}$ ), and the boreal forests of Alaska, Canada, and Russia. During the dry season, bbPOA concentrations increase significantly (e.g., $10-50 \mu \mathrm{g} \mathrm{m}^{-3}$ during January over the Congo Basin), while during the wet season they are much lower (e.g., 0.5-3 $\mu \mathrm{g} \mathrm{m}^{-3}$ during July over the Congo Basin).

\subsection{Secondary organic aerosol from SVOCs}

SVOCs are emitted in both the aerosol and gas phase and can be transferred from phase to phase due to cooling and dilution as the air masses travel from their sources. SVOCs in the gas phase can be oxidized and possibly re-condense to the aerosol phase, forming secondary organic aerosols (SOAsv). In ORACLE SOA-sv is subdivided into fSOA-sv and bbSOA-sv depending on its source as described in Sect. 3.5. fSOA-sv and bbSOA-sv concentrations are high according to our simulation downwind of polluted urban areas and megacities and the major rainforests (Fig. 6). However, as most of the SVOCs are in the aerosol phase after emissions (as POA) and remain there without undergoing chemical reactions during their atmospheric lifetime, fSOA-sv and bbSOA-sv concentrations are significantly lower compared to the corresponding fPOA and bbPOA concentrations (Figs. 5 and 6).

\section{fSOA-sv}

The global and land average surface concentrations of fSOAsv are 0.03 and $0.04 \mu \mathrm{g} \mathrm{m}^{-3}$, respectively (Table 7, Fig. 6a). fSOA-sv disperses over the continents but remains at low levels in most cases (lower than $0.2 \mu \mathrm{g} \mathrm{m}^{-3}$ ). The highest concentrations of fSOA-sv are modeled over India and 
Table 7. Global and land average surface concentration and tropospheric burden of organic aerosol components. The fractional contribution of each component to total $\mathrm{OA}$ is listed in parentheses.

\begin{tabular}{|c|c|c|c|c|c|c|c|c|}
\hline OA component & fPOA & bbPOA & fSOA-sv & bbSOA-sv & fSOA-iv & bbSOA-iv & aSOA-v & bSOA-v \\
\hline & $0.11(7 \%)$ & $0.16(11 \%)$ & & & $0.22(15 \%)$ & & $0.23(15 \%)$ & $0.28(19 \%)$ \\
\hline Land average $\left(\mu \mathrm{g} \mathrm{m}^{-3}\right)$ & $0.22(8 \%)$ & $0.39(14 \%)$ & $0.04(1 \%)$ & $0.07(2 \%)$ & $0.35(12 \%)$ & $0.74(26 \%)$ & $0.39(13 \%)$ & $0.70(24 \%)$ \\
\hline Tropospheric burden $(\mathrm{Tg})$ & $0.11(4 \%)$ & $0.12(4 \%)$ & $0.06(2 \%)$ & $0.1(3 \%)$ & $0.5(17 \%)$ & $0.91(30 \%)$ & $0.65(22 \%)$ & $0.55(18 \%)$ \\
\hline
\end{tabular}

(a) FPOA

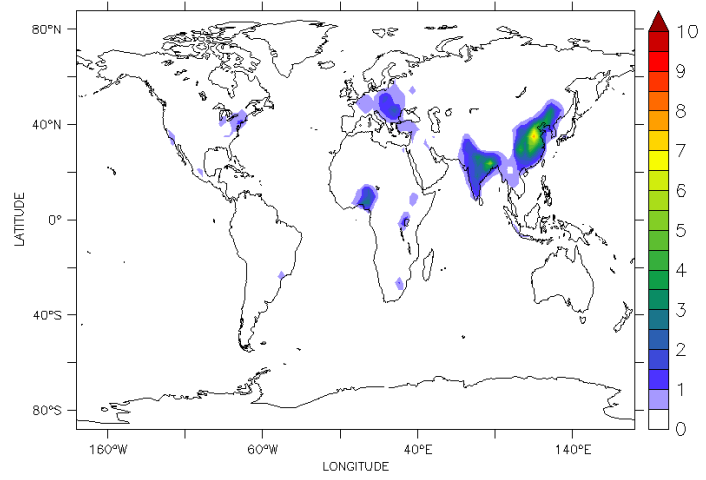

(b) bbPOA

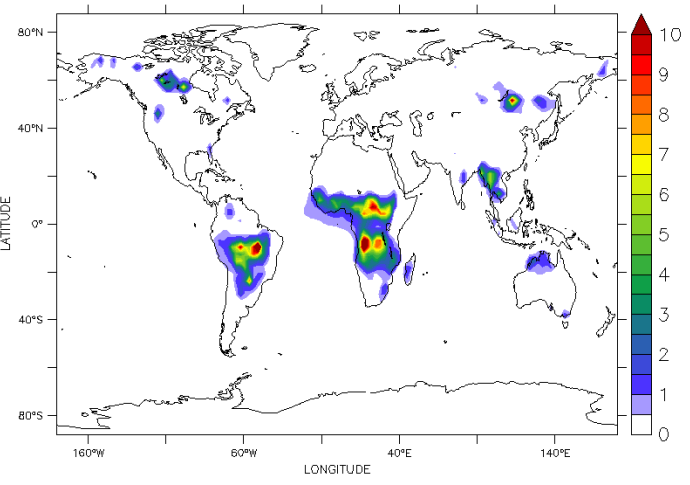

Figure 5. Modeled average surface concentrations (in $\mu \mathrm{g} \mathrm{m}^{-3}$ ) of (a) POA from fuel combustion (fPOA) and (b) POA from biomass burning emissions (bbPOA) during the years 2005-2009.

Bangladesh $\left(0.3-0.7 \mu \mathrm{g} \mathrm{m}^{-3}\right)$, and in the greater Beijing area and Nigeria $\left(0.1-0.5 \mu \mathrm{g} \mathrm{m}^{-3}\right)$.

\section{bbSOA-SV}

The global and land average surface concentrations of bbSOA-sv are 0.05 and $0.07 \mu \mathrm{g} \mathrm{m}^{-3}$, respectively (Table 7, Fig. 6b). bbSOA-sv has higher concentrations in the Southern Hemisphere, where the main rainforests of the world are located (Amazon, Congo Basin, part of SE Asia) and the meteorological conditions favor the partition of SVOC emissions into the gas phase, where they are subject to oxidation. The highest bbSOA-sv concentrations (up to $1 \mu \mathrm{g} \mathrm{m}^{-3}$ ) are calculated over the west coast of central Africa, affected by the biomass burning emissions from the Congo Basin rainforest. These emissions are the source of the relatively high bbSOA-sv concentrations $\left(0.3-0.7 \mu \mathrm{g} \mathrm{m}^{-3}\right)$ that are calculated over the southern Atlantic Ocean. The concentration of bbSOA-sv over the Amazon Basin is up to $0.7 \mu \mathrm{g} \mathrm{m}^{-3}$. The atmosphere over the Pacific and Indian oceans is also affected by biomass burning emissions from the Amazon rainforest and the rainforests of Southeast Asia, respectively (bbSOA-sv concentration is $0.1-0.3 \mu \mathrm{g} \mathrm{m}^{-3}$ ). Over the boreal forests, bbSOA-sv reaches low levels (less than $0.1 \mu \mathrm{g} \mathrm{m}^{-3}$ ) as most of the biomass burning SVOCs are emitted directly into the aerosol phase, forming bbPOA.

\subsection{Secondary organic aerosol from IVOCs}

IVOCs are emitted in the gas phase, where they react with $\mathrm{OH}$, becoming less volatile and more chemically processed, and condense to the aerosol phase to produce secondary organic aerosol (SOA-iv). SOA-iv is subdivided into fSOAiv and bbSOA-iv depending on the source as described in Sect. 3.5. In the current application, IVOC emissions are assumed to be 4 times higher than those of SVOC (Table 4). Therefore, IVOCs are a significant source of SOA and the SOA-iv concentration by far exceeds that of SOASV and POA (Figs. 5-7). Furthermore, the effective longrange transport of IVOCs results in the formation of significant SOA-iv amounts remote from the sources (Fig. 7). This is consistent with several field campaigns over megacities which have shown that the concentration of primary combustion organic particles decreases with distance from the urban source areas due to evaporation and deposition, remaining at low levels in surrounding areas, while secondary oxygenated and photochemically processed organics remain in high concentrations in suburban and rural sites (Aiken et al., 2009; Hildebrandt et al., 2010; Morgan et al., 2010).

\section{fSOA-iv}

The global and land average surface concentrations of fSOAiv are 0.22 and $0.35 \mu^{-3} \mathrm{~m}^{-3}$, respectively (Table 7, Fig. 7a). This is 2 times higher than the corresponding average surface concentration of IPOA, even though the peak concentrations of fSOA-iv and fPOA are similar $\left(7 \mu \mathrm{g} \mathrm{m}^{-3}\right.$ over 
(a) fSOA-sv

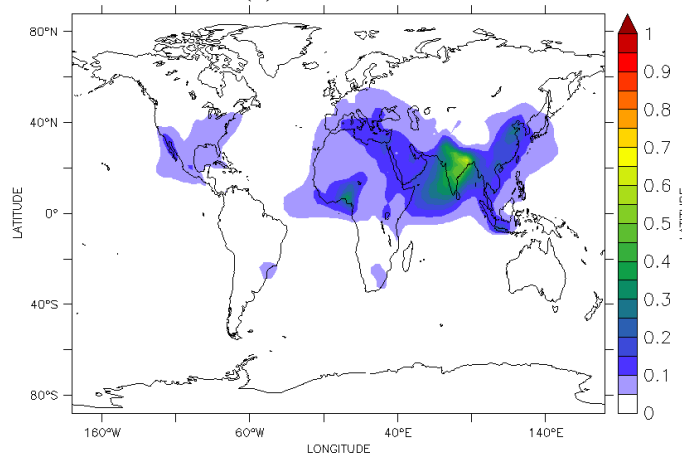

(b) bbSOA-sv

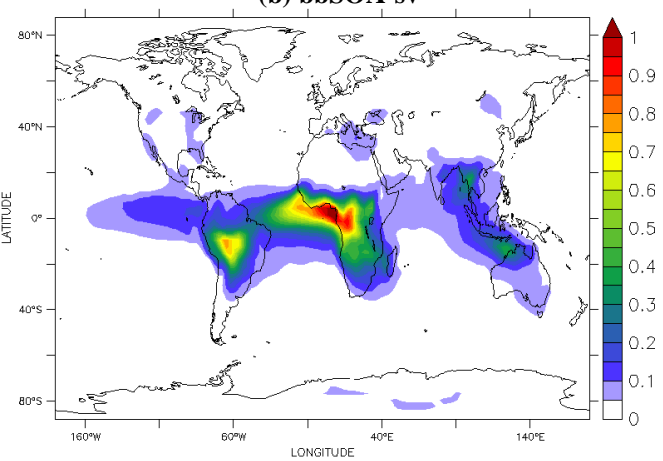

Figure 6. Modeled average surface concentrations (in $\mu \mathrm{g} \mathrm{m}^{-3}$ ) of (a) SOA-sv from the oxidation of SVOCs from fuel combustion (fSOA-sv) and (b) SOA-sv from the oxidation SVOCs from biomass burning emissions (bbSOA-sv) during the years 2005-2009.

(a) FSOA-iv

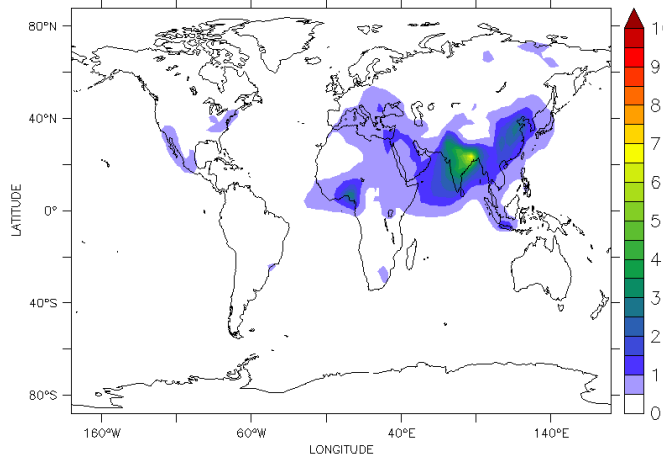

(b) bbSOA-iv

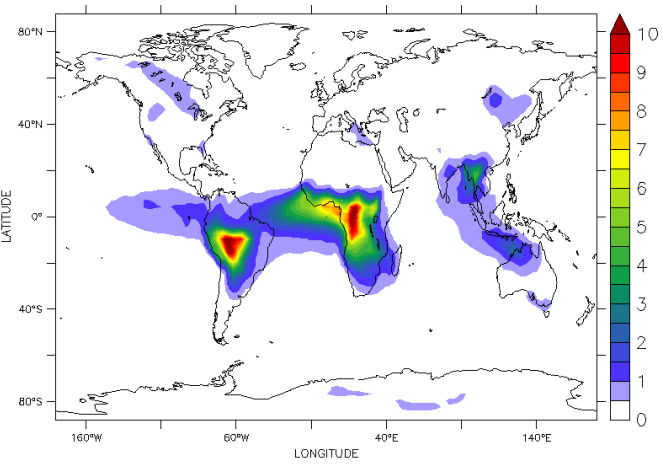

Figure 7. Modeled average surface concentrations (in $\mu \mathrm{g} \mathrm{m}^{-3}$ ) of (a) SOA-iv from the oxidation of IVOCs from fuel combustion (fSOA-iv) and (b) SOA-iv from the oxidation IVOCs from biomass burning emissions (bbSOA-iv) during the years 2005-2009.

Bangladesh and $8 \mu \mathrm{g} \mathrm{m}^{-3}$ over the greater Beijing area, respectively). This difference indicates that fSOA-iv is more regionally distributed compared to fPOA, due to the effects of long-range transport of IVOC emissions on fSOA-iv formation. The model calculates a continental background of around $0.5 \mu \mathrm{g} \mathrm{m}^{-3}$ for fSOA-iv. The highest fSOA-iv concentrations are modeled over India and Bangladesh (3$\left.7 \mu \mathrm{g} \mathrm{m}^{-3}\right)$, eastern China $\left(1-4 \mu \mathrm{g} \mathrm{m}^{-3}\right)$, and western Africa $\left(1-4 \mu \mathrm{g} \mathrm{m}^{-3}\right)$. The Balkan Peninsula and eastern Mediterranean are strongly influenced by long-range transport of IVOC emissions from eastern Europe (the fSOA-iv concentration is $0.5-1 \mathrm{~g} \mathrm{~m} \mathrm{~m}^{-3}$ ). fSOA-iv concentrations are also significant over the Arabian Peninsula (around $1 \mu \mathrm{g} \mathrm{m}^{-3}$ ), and western and southern Africa $\left(0.5-1 \mu \mathrm{g} \mathrm{m}^{-3}\right)$. Over North America fSOA-iv concentrations are relatively high over a large area covering the eastern USA, the Californian Peninsula and northern Mexico $\left(0.5-1 \mu \mathrm{g} \mathrm{m}^{-3}\right)$, while over South America high fSOA-iv concentrations occur mostly over Rio de Janeiro $\left(0.5-1 \mu \mathrm{g} \mathrm{m}^{-3}\right)$. Long-range transport is also important for the modeled fSOA-iv concentrations over the oceans. This is mostly evident over the Arabian Sea, where the fSOA-iv concentration is $1-2 \mu \mathrm{g} \mathrm{m}^{-3}$, mainly due to long-range transport of fSOA-iv from India. The Atlantic Ocean atmosphere is influenced by IVOC emissions from western Africa and the fSOA-iv concentration over this region is estimated at $0.5-1 \mu \mathrm{g} \mathrm{m}^{-3}$. Over the Pacific Ocean fSOA-iv is sensitive to long-range transport from the Los Angeles and Mexico City areas and from Beijing and other big cities in eastern China, resulting in significant concentrations off the west coast of California (up to $0.5-1 \mu \mathrm{g} \mathrm{m}^{-3}$ ) and the Pacific Rim (up to $0.5-1.5 \mu \mathrm{g} \mathrm{m}^{-3}$ ).

\section{bbSOA-iv}

The modeled global and land average surface concentrations of bbSOA-iv are 0.42 and $0.74 \mu \mathrm{g} \mathrm{m}^{-3}$, respectively (Table 7, Fig. 7b). Similar to fSOA-iv, bbSOA-iv is 2 times higher than bbPOA and disperses over a wide area covering most of South America, central, and southern Africa, eastern Russia, Southeast Asia, and Indonesia due to emissions from the major rainforests and savannas in the Southern Hemisphere, the tropics, and the boreal forests in the Northern Hemisphere. The highest bbSOA-iv concentrations are modeled over the Amazon and Congo Basin rainforests $\left(5-10 \mu \mathrm{g} \mathrm{m}^{-3}\right)$. bbSOA-iv concentrations are also high over 
(a) bSOA-v

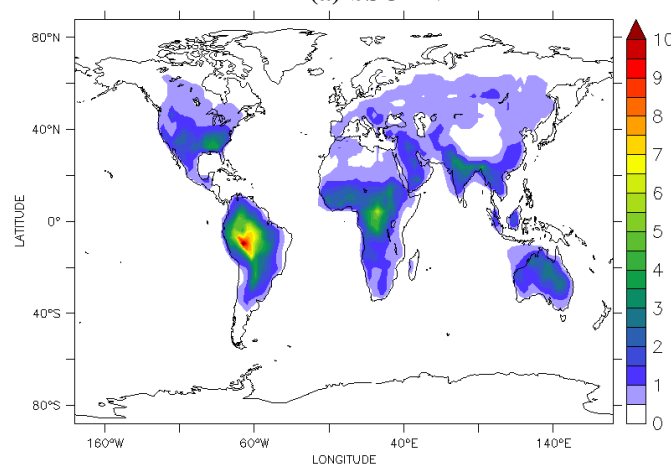

(b) aSOA-v

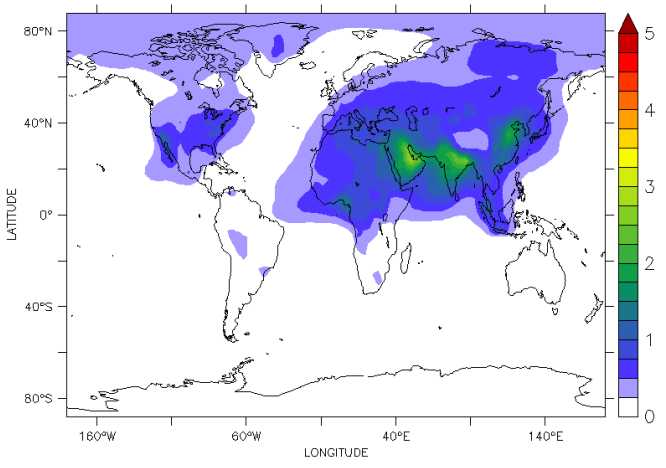

Figure 8. Modeled average surface concentrations (in $\mu \mathrm{g} \mathrm{m}^{-3}$ ) of (a) SOA-v from the oxidation of biogenic VOC emissions (bSOA-v) and (b) SOA-v from the oxidation of anthropogenic VOC emissions (aSOA-v) during the years 2005-2009.

Southeast Asia (up to $1-5 \mu \mathrm{g} \mathrm{m}^{-3}$ ) and the boreal forests of Alaska, Canada, and Russia $\left(0.5-1.5 \mu \mathrm{g} \mathrm{m}^{-3}\right)$. The subtropical west coasts of Africa, South America, and Indonesia are strongly influenced by long-range transport of bbSOA-iv. The strongest transport effect is expected over the Atlantic Ocean, where biomass burning IVOC emissions can travel thousands of kilometers from the sources (e.g., the Congo Basin rainforest), resulting in significant bbSOA-iv concentrations $\left(2-6 \mu \mathrm{g} \mathrm{m}^{-3}\right)$.

\subsection{Secondary organic aerosol from VOCs}

SOA-V is formed from the oxidation of biogenic and anthropogenic VOCs. Global VOC emissions are dominated by biogenic compounds from vegetated areas (Kanakidou et al., 2005). However, anthropogenic VOCs, emitted in urban areas, can also contribute significantly to SOA formation, especially considering the aging reactions of aSOA-v.

\section{bSOA-v}

The global and land average surface concentrations of bSOA$\mathrm{v}$ are $0.28 \mu \mathrm{g} \mathrm{m}^{-3}$ (Fig. 8a). EMAC calculates highest bSOA$\mathrm{v}$ concentrations over the Amazon rainforest $\left(5-10 \mu \mathrm{g} \mathrm{m}^{-3}\right)$, mostly due to the oxidation of isoprene. Over the Congo Basin rainforest, where isoprene emissions are similar to monoterpene emissions, the bSOA-v average surface concentration is $3-6 \mu \mathrm{g} \mathrm{m}^{-3}$. bSOA-v concentrations are also relatively high over Southeast Asia $\left(2-4 \mu \mathrm{g} \mathrm{m}^{-3}\right)$, the southeastern USA and Australia $\left(2-5 \mu \mathrm{g} \mathrm{m}^{-3}\right)$, and Europe (0.5$\left.1.5 \mu \mathrm{g} \mathrm{m}^{-3}\right)$.

\section{aSOA-v}

The global and land average surface concentrations of aSOA$\mathrm{v}$ are $0.23 \mu \mathrm{g} \mathrm{m}^{-3}$ (Fig. 8b). Photochemical aging adds significantly to aSOA-v since only $10 \%$ of the modeled aSOA-v is formed from the first photooxidation step of aSOA-v. The remaining $90 \%$ is formed through the continued oxidation of
aSOA-v. The aggressive aging of aSOA-v results in a wider distribution of aSOA-v than bSOA-v and in a significant contribution of aSOA-v to the total SOA-v (45\%). The aSOA$\mathrm{v}$ is modeled to have a continental background of around $0.5 \mu \mathrm{g} \mathrm{m}^{-3}$ and relatively high concentrations in the vicinity of urban areas. The highest concentrations occur over India, Bangladesh, and the Persian Gulf $\left(2-3 \mu \mathrm{g} \mathrm{m}^{-3}\right)$. Over India, aromatics dominate the aVOC emissions ( $57 \%$ ), followed by alkanes $(29 \%)$ and olefins $(14 \%)$. Over the Persian Gulf region, alkenes are the dominant aVOC $(65 \%)$, followed by aromatics $(33 \%)$ and olefins $(2 \%)$. However, these numbers do not proportionally reflect the VOC contributions to the aSOA-v formation since different types of aVOC have different aerosol yields. Over Europe, the highest aSOA-v concentrations occur over the Mediterranean Basin $\left(0.5-1 \mu \mathrm{g} \mathrm{m}^{-3}\right)$ due to the long-range transport of aSOA-v from central European emissions. Over the USA, aSOA-v concentrations are relatively high over California and the eastern USA (around $1 \mu \mathrm{g} \mathrm{m}^{-3}$ ).

\subsection{Chemical composition of $\mathrm{OA}$}

Table 7 summarizes the modeled global average chemical composition of OA at the surface. Most OA is SOA $(82 \%)$ formed from the oxidation of organic compounds in the gas phase. SOA consists of $52 \%$ SOA-iv, $42 \%$ SOA-v, and $6 \%$ SOA-sv. The important contribution of SOA-iv to the overall SOA mass is attributed to the fact that strong fuelcombustion-related and biomass burning IVOC emissions react with atmospheric oxidants to form low-volatility products that condense into the particle phase as SOA-iv. This result further emphasizes the importance of the oxidation of IVOCs as an additional source of OA and implies that global and regional models that do not account for IVOCs could underestimate OA formation by as much as $40 \%$. In addition, the model results highlight the importance of anthropogenic emissions to global OA formation. In particular it calculates that one-third of OA originates from anthropogenic sources. 
(a) POA

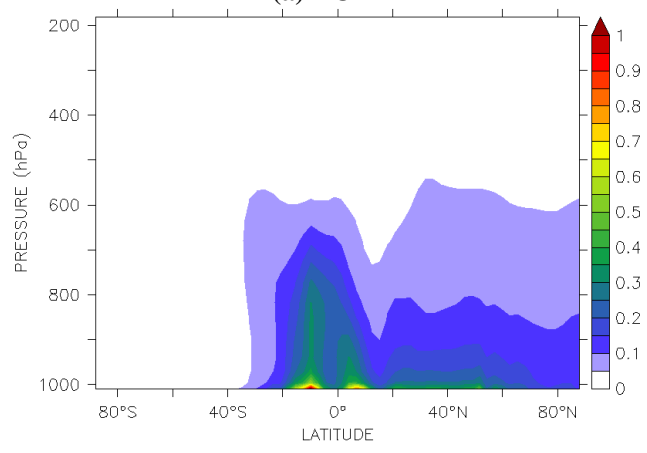

(b) SOA

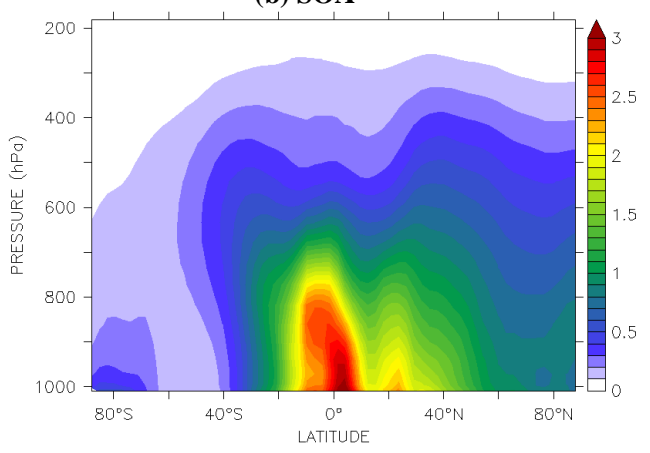

Figure 9. Modeled average zonal concentrations (in $\mu \mathrm{g} \mathrm{m}^{-3}$ ) of (a) POA (sum of fPOA and bbPOA) and (b) SOA (sum of fSOA-sv, bbSOAsv, fSOA-iv, bbSOA-iv, aSOA-v, and bSOA-v) during the years 2005-2009.

Even if this fraction may be overestimated due to the aggressive aging of IVOCs and aVOCs applied in this study, it corroborates the findings of recent studies that highlight the potentially large impact of anthropogenic OA, especially SOA, on the global aerosol load (Spracklen et al., 2011; Carslaw et al., 2013; Lee et al., 2013).

At higher altitudes the production of SOA is enhanced since organic gases can be efficiently transported vertically and oxidized, forming lower volatility SOA (Fig. 9). In addition, the produced SOA at higher altitudes has a relatively long lifetime since it is less subjected to wet and dry deposition. This results in a higher fraction of SOA in total OA in the free troposphere than at the surface $(92 \%$ compared to $82 \%$ at the surface). Furthermore, in contrast to the surface OA composition, the fraction of aSOA-v in the free troposphere is calculated to be higher than bSOA-v since the latter is not allowed to participate in additional photochemical reactions (Table 7). The modeled tropospheric burden of POA is $0.23 \mathrm{Tg}$, the sum of SOA-sv and SOA-iv is $1.57 \mathrm{Tg}$, and SOA-v is $1.2 \mathrm{Tg}$. Pye and Seinfeld (2010) estimated $0.03 \mathrm{Tg}$ of POA, $0.90 \mathrm{Tg}$ of SOA-sv and SOA-iv, and $0.71 \mathrm{Tg}$ of SOA-v, while Jathar et al. (2011) found $0.09 \mathrm{Tg}$ of POA, 1.25 Tg of SOA-sv and SOA-iv, and 1.02 Tg of SOA-v. Farina et al. (2010) and Jo et al. (2013) did not account for SOA-sv and SOA-iv and calculated 1.1 and $0.8 \mathrm{Tg}$ of POA, respectively, and 0.98 and $1.16 \mathrm{Tg}$ of SOA-v, respectively.

\section{Conclusions}

A new module describing the organic composition of aerosols and the evolution in the atmosphere has been developed and implemented into the global EMAC model. ORACLE treats fossil-fuel-, biofuel-, and biomass-burningrelated aerosol emissions as semivolatile and chemically reactive, and also accounts for the emissions and oxidation of IVOCs as an additionally important source of OA. Furthermore, it considers the formation of SOA from the oxidation of anthropogenic and biogenic VOC precursors. The model employs the volatility basis set theory to simulate the emissions, chemical reactions, and phase partitioning of all OA components.

The comparison of the model results with measured ambient OA mass concentrations illustrates that, by treating fuel combustion and biomass burning aerosol emissions as semivolatile and reactive, and accounting for emissions and oxidation of IVOCs and traditional VOCs, the model realistically represents the sources, chemistry, and properties of $\mathrm{OA}$, and reproduces the measured concentrations of OA over urban and forested areas. In contrast to previous CCMs that treat POA as nonvolatile and nonreactive, the ORACLE module calculates that most of the OA is SOA $(82 \%)$. Furthermore, approximately one-third of OA is estimated to originate from anthropogenic sources. Such high anthropogenic OA fractions challenge the results of the traditional CCMs and add to the most recent findings that suggest a strong contribution of anthropogenic sources to global OA concentrations.

On average, model calculated $\mathrm{OA}$ at the surface consists of $18 \%$ POA, $5 \%$ SOA-sv, $43 \%$ SOA-iv, and $34 \%$ SOA$\mathrm{v}$. The tropospheric burdens of OA components are modeled to be $0.23 \mathrm{Tg}$ POA, $0.16 \mathrm{Tg}$ SOA-sv, $1.41 \mathrm{Tg}$ SOA-iv, and $1.2 \mathrm{Tg}$ SOA-v. POA concentrations are particularly high close to biomass burning regions (forest and savanna fires) and fuel-combustion-dominated sources (urban and industrial regions), though they decrease rapidly during atmospheric transport. SOA-sv concentrations are 4 to 5 times lower than POA concentrations since most of the SVOCs are emitted directly in the aerosol phase. IVOCs, on the other hand, are expected to be important SOA precursors, resulting in high SOA-iv concentrations that are widely dispersed over the continents and the tropical oceans, being subject to the long-range transport of IVOC emissions. SOA-v accounts for $34 \%$ of the total SOA concentration and originates from biogenic sources $(55 \%)$ and anthropogenic sources $(45 \%)$. In the current application, only anthropogenic SOA-v has been 
allowed to participate in aging reactions, which considerably increases the modeled aSOA-v concentration.

The ORACLE module subdivides OA into several compounds, allowing the quantification of primary versus secondary as well as biogenic versus anthropogenic contributions to OA concentrations. Such fundamental information can shed light on long-term changes in OA abundance, and hence project the effects of OA on future air quality and climate. ORACLE is well suited for studying the climatic impact of OA as it captures the dynamic aging of OA and its atmospheric evolution by becoming increasingly oxidized, less volatile, and more hygroscopic. Future applications will also include the effects on cloud condensation nuclei and indirect aerosol effects on climate. Furthermore, the detailed composition of OA, computed by ORACLE, can be used to directly compare model predictions with the latest aerosol mass spectrometer (AMS) factor analysis data, which is planned as a next application.

Overall, ORACLE is a flexible module that efficiently describes the organic aerosol composition and chemical evolution in the atmosphere. Sensitivity studies of the influence of several parameters (such as reaction constants, aerosol yields, and SVOC and IVOC emission fractions) on the model calculations will be conducted in a planned future study and used, along with AMS factor analysis data taken around the world, to optimize the model configuration to further improve the estimates of OA concentrations and investigate their role in air quality and climate.

\section{Code availability}

The complete ORACLE code can be obtained upon request by emailing the first author. To use ORACLE as part of EMAC, please first apply for an ECHAM5 and a MESSy license. The GCM ECHAM5 was developed at the Max Planck Institute for Meteorology in Hamburg (see http://www.mpimet.mpg.de/en/wissenschaft/ modelle/echam/echam5.html). The Modular Earth Submodel System (MESSy) is continuously further developed and applied by a consortium of institutions, initiated by the Max Planck Institute for Chemistry. The usage of MESSy and access to the source code is licensed to all affiliates of institutions that are members of the MESSy Consortium. Institutions can become a member of the MESSy Consortium by signing the MESSy Memorandum of Understanding. More information can be found on the MESSy Consortium website (http://www.messy-interface.org).

Acknowledgements. The research leading to these results has received funding from the European Research Council through the European Union's Seventh Framework Programme (FP7/2007-2013)/ERC grant agreement no. 226144. V. A. Karydis acknowledges support from a FP7 Marie Curie Career Integration Grant (project reference 618349).
The service charges for this open access publication have been covered by the Max Planck Society.

Edited by: G. Mann

\section{References}

Aiken, A. C., Decarlo, P. F., Kroll, J. H., Worsnop, D. R., Huffman, J. A., Docherty, K. S., Ulbrich, I. M., Mohr, C., Kimmel, J. R., Sueper, D., Sun, Y., Zhang, Q., Trimborn, A., Northway, M., Ziemann, P. J., Canagaratna, M. R., Onasch, T. B., Alfarra, M. R., Prevot, A. S. H., Dommen, J., Duplissy, J., Metzger, A., Baltensperger, U., and Jimenez, J. L.: O/C and OM/OC ratios of primary, secondary, and ambient organic aerosols with high-resolution time-of-flight aerosol mass spectrometry, Environmen. Sci. Technol., 42, 4478-4485, 2008.

Aiken, A. C., Salcedo, D., Cubison, M. J., Huffman, J. A., DeCarlo, P. F., Ulbrich, I. M., Docherty, K. S., Sueper, D., Kimmel, J. R., Worsnop, D. R., Trimborn, A., Northway, M., Stone, E. A., Schauer, J. J., Volkamer, R. M., Fortner, E., de Foy, B., Wang, J., Laskin, A., Shutthanandan, V., Zheng, J., Zhang, R., Gaffney, J., Marley, N. A., Paredes-Miranda, G., Arnott, W. P., Molina, L. T., Sosa, G., and Jimenez, J. L.: Mexico City aerosol analysis during MILAGRO using high resolution aerosol mass spectrometry at the urban supersite (T0) - Part 1: Fine particle composition and organic source apportionment, Atmos. Chem. Phys., 9, 6633-6653, doi:10.5194/acp-9-6633-2009, 2009.

Athanasopoulou, E., Vogel, H., Vogel, B., Tsimpidi, A. P., Pandis, S. N., Knote, C., and Fountoukis, C.: Modeling the meteorological and chemical effects of secondary organic aerosols during an EUCAARI campaign, Atmos. Chem. Phys., 13, 625-645, doi:10.5194/acp-13-625-2013, 2013.

Bergström, R., Denier van der Gon, H. A. C., Prévôt, A. S. H., Yttri, K. E., and Simpson, D.: Modelling of organic aerosols over Europe (2002-2007) using a volatility basis set (VBS) framework: application of different assumptions regarding the formation of secondary organic aerosol, Atmos. Chem. Phys., 12, 8499-8527, doi:10.5194/acp-12-8499-2012, 2012.

Brito, J., Rizzo, L. V., Morgan, W. T., Coe, H., Johnson, B., Haywood, J., Longo, K., Freitas, S., Andreae, M. O., and Artaxo, P.: Ground-based aerosol characterization during the South American Biomass Burning Analysis (SAMBBA) field experiment, Atmos. Chem. Phys., 14, 12069-12083, doi:10.5194/acp-1412069-2014, 2014.

Browne, E. C., Min, K.-E., Wooldridge, P. J., Apel, E., Blake, D. R., Brune, W. H., Cantrell, C. A., Cubison, M. J., Diskin, G. S., Jimenez, J. L., Weinheimer, A. J., Wennberg, P. O., Wisthaler, A., and Cohen, R. C.: Observations of total $\mathrm{RONO}_{2}$ over the boreal forest: $\mathrm{NO}_{\mathrm{x}}$ sinks and $\mathrm{HNO}_{3}$ sources, Atmos. Chem. Phys., 13, 4543-4562, doi:10.5194/acp-13-4543-2013, 2013.

Capes, G., Johnson, B., McFiggans, G., Williams, P. I., Haywood, J., and Coe, H.: Aging of biomass burning aerosols over West Africa: Aircraft measurements of chemical composition, microphysical properties, and emission ratios, J. Geophys. Res.Atmos., 113, D00C15, doi:10.1029/2008jd009845, 2008.

Capes, G., Murphy, J. G., Reeves, C. E., McQuaid, J. B., Hamilton, J. F., Hopkins, J. R., Crosier, J., Williams, P. I., and Coe, 
H.: Secondary organic aerosol from biogenic VOCs over West Africa during AMMA, Atmos. Chem. Phys., 9, 3841-3850, doi:10.5194/acp-9-3841-2009, 2009.

Carslaw, K. S., Lee, L. A., Reddington, C. L., Mann, G. W., and Pringle, K. J.: The magnitude and sources of uncertainty in global aerosol, Faraday Discuss., 165, 495-512, 2013.

Carter, W. P. L.: Documentation of the SAPRC-99 chemical mechanism for VOC reactivity assessment, Report to the California air resources board, available at: http://www.cert.ucr.edu/ carter/ absts.htm\#saprc99 (last access: 7 August 2014), 2000.

Chen, Q., Farmer, D. K., Schneider, J., Zorn, S. R., Heald, C. L., Karl, T. G., Guenther, A., Allan, J. D., Robinson, N., Coe, H., Kimmel, J. R., Pauliquevis, T., Borrmann, S., Poeschl, U., Andreae, M. O., Artaxo, P., Jimenez, J. L., and Martin, S. T.: Mass spectral characterization of submicron biogenic organic particles in the Amazon Basin, Geophys. Res. Lett., 36, L20806, doi:10.1029/2009g1039880, 2009.

Clarke, L., Edmonds, J., Jacoby, H., Pitcher, H., Reilly, J., and Richels, R.: Scenarios of greenhouse gas emissions and atmospheric concentrations (Part A) and review of integrated scenario development and application (Part B), A report by the US climate change science program and the subcommittee on global change research, 2007.

de Meij, A., Pozzer, A., Pringle, K. J., Tost, H., and Lelieveld, J.: EMAC model evaluation and analysis of atmospheric aerosol properties and distribution with a focus on the Mediterranean region, Atmos. Res., 114, 38-69, 2012.

Dentener, F., Kinne, S., Bond, T., Boucher, O., Cofala, J., Generoso, S., Ginoux, P., Gong, S., Hoelzemann, J. J., Ito, A., Marelli, L., Penner, J. E., Putaud, J.-P., Textor, C., Schulz, M., van der Werf, G. R., and Wilson, J.: Emissions of primary aerosol and precursor gases in the years 2000 and 1750 prescribed data-sets for AeroCom, Atmos. Chem. Phys., 6, 4321-4344, doi:10.5194/acp-64321-2006, 2006.

Donahue, N. M., Robinson, A. L., Stanier, C. O., and Pandis, S. N.: Coupled partitioning, dilution, and chemical aging of semivolatile organics, Environ. Sci. Technol., 40, 2635-2643, 2006.

Donahue, N. M., Henry, K. M., Mentel, T. F., Kiendler-Scharr, A., Spindler, C., Bohn, B., Brauers, T., Dorn, H. P., Fuchs, H., Tillmann, R., Wahner, A., Saathoff, H., Naumann, K.-H., Moehler, O., Leisner, T., Mueller, L., Reinnig, M.-C., Hoffmann, T., Salo, K., Hallquist, M., Frosch, M., Bilde, M., Tritscher, T., Barmet, P., Praplan, A. P., DeCarlo, P. F., Dommen, J., Prevot, A. S. H., and Baltensperger, U.: Aging of biogenic secondary organic aerosol via gas-phase $\mathrm{OH}$ radical reactions, Proc. Natl. Aca. Sci. USA, 109, 13503-13508, doi:10.1073/pnas.1115186109, 2012.

Donahue, N. M., Chuang, W., Epstein, S. A., Kroll, J. H., Worsnop, D. R., Robinson, A. L., Adams, P. J., and Pandis, S. N.: Why do organic aerosols exist? Understanding aerosol lifetimes using the two-dimensional volatility basis set, Environ. Chem., 10, 151157, 2013.

Farina, S. C., Adams, P. J., and Pandis, S. N.: Modeling global secondary organic aerosol formation and processing with the volatility basis set: Implications for anthropogenic secondary organic aerosol, J. Geophys. Res.-Atmos., 115, D09202, doi:10.1029/2009jd013046, 2010.

Fountoukis, C., Racherla, P. N., Denier van der Gon, H. A. C., Polymeneas, P., Charalampidis, P. E., Pilinis, C., Wiedensohler,
A., Dall'Osto, M., O’Dowd, C., and Pandis, S. N.: Evaluation of a three-dimensional chemical transport model (PMCAMx) in the European domain during the EUCAARI May 2008 campaign, Atmos. Chem. Phys., 11, 10331-10347, doi:10.5194/acp11-10331-2011, 2011.

Fountoukis, C., Megaritis, A. G., Skyllakou, K., Charalampidis, P. E., Pilinis, C., Denier van der Gon, H. A. C., Crippa, M., Canonaco, F., Mohr, C., Prévôt, A. S. H., Allan, J. D., Poulain, L., Petäjä, T., Tiitta, P., Carbone, S., Kiendler-Scharr, A., Nemitz, E., O'Dowd, C., Swietlicki, E., and Pandis, S. N.: Organic aerosol concentration and composition over Europe: insights from comparison of regional model predictions with aerosol mass spectrometer factor analysis, Atmos. Chem. Phys., 14, 9061-9076, doi:10.5194/acp-14-9061-2014, 2014.

Grieshop, A. P., Logue, J. M., Donahue, N. M., and Robinson, A. L.: Laboratory investigation of photochemical oxidation of organic aerosol from wood fires 1: measurement and simulation of organic aerosol evolution, Atmos. Chem. Phys., 9, 1263-1277, doi:10.5194/acp-9-1263-2009, 2009.

Heald, C. L., Jacob, D. J., Park, R. J., Russell, L. M., Huebert, B. J., Seinfeld, J. H., Liao, H., and Weber, R. J.: A large organic aerosol source in the free troposphere missing from current models, Geophys. Res. Lett., 32, L18809, doi:10.1029/2005g1023831, 2005.

Hennigan, C. J., Miracolo, M. A., Engelhart, G. J., May, A. A., Presto, A. A., Lee, T., Sullivan, A. P., McMeeking, G. R., Coe, H., Wold, C. E., Hao, W.-M., Gilman, J. B., Kuster, W. C., de Gouw, J., Schichtel, B. A., Collett Jr., J. L., Kreidenweis, S. M., and Robinson, A. L.: Chemical and physical transformations of organic aerosol from the photo-oxidation of open biomass burning emissions in an environmental chamber, Atmos. Chem. Phys., 11, 7669-7686, doi:10.5194/acp-11-7669-2011, 2011.

Hildebrandt, L., Donahue, N. M., and Pandis, S. N.: High formation of secondary organic aerosol from the photo-oxidation of toluene, Atmos. Chem. Phys., 9, 2973-2986, doi:10.5194/acp-92973-2009, 2009.

Hildebrandt, L., Engelhart, G. J., Mohr, C., Kostenidou, E., Lanz, V. A., Bougiatioti, A., DeCarlo, P. F., Prevot, A. S. H., Baltensperger, U., Mihalopoulos, N., Donahue, N. M., and Pandis, S. N.: Aged organic aerosol in the Eastern Mediterranean: the Finokalia Aerosol Measurement Experiment - 2008, Atmos. Chem. Phys., 10, 4167-4186, doi:10.5194/acp-10-4167-2010, 2010.

Hildemann, L. M., Cass, G. R., and Markowski, G. R.: A dilution stack sampler for collection of organic aerosol emissions-Desigh, characterization and filed-tests, Aerosol Sci. Technol., 10, 193204, 1989.

Hodzic, A., Jimenez, J. L., Madronich, S., Canagaratna, M. R., DeCarlo, P. F., Kleinman, L., and Fast, J.: Modeling organic aerosols in a megacity: potential contribution of semi-volatile and intermediate volatility primary organic compounds to secondary organic aerosol formation, Atmos. Chem. Phys., 10, 5491-5514, doi:10.5194/acp-10-5491-2010, 2010.

IPCC: (Intergovernmental Panel on Climate Change): The physical science basis, Contribution of working group I to the fifth assessment report of the intergovernmental panel on climate change, edited by: Stocker, T. F., Qin, D., Plattner, G.-K., Tignor, M., Allen, S. K., Boschung, J., Nauels, A., Xia, Y., Bex, V., and Midgley, P. M., Cambridge University Press, Cambridge, United Kingdom and New York, NY, USA, 2013. 
Jathar, S. H., Farina, S. C., Robinson, A. L., and Adams, P. J.: The influence of semi-volatile and reactive primary emissions on the abundance and properties of global organic aerosol, Atmos. Chem. Phys., 11, 7727-7746, doi:10.5194/acp-11-77272011, 2011.

Jimenez, J. L., Canagaratna, M. R., Donahue, N. M., Prevot, A. S. H., Zhang, Q., Kroll, J. H., DeCarlo, P. F., Allan, J. D., Coe, H., Ng, N. L., Aiken, A. C., Docherty, K. S., Ulbrich, I. M., Grieshop, A. P., Robinson, A. L., Duplissy, J., Smith, J. D., Wilson, K. R., Lanz, V. A., Hueglin, C., Sun, Y. L., Tian, J., Laaksonen, A., Raatikainen, T., Rautiainen, J., Vaattovaara, P., Ehn, M., Kulmala, M., Tomlinson, J. M., Collins, D. R., Cubison, M. J., Dunlea, E. J., Huffman, J. A., Onasch, T. B., Alfarra, M. R., Williams, P. I., Bower, K., Kondo, Y., Schneider, J., Drewnick, F., Borrmann, S., Weimer, S., Demerjian, K., Salcedo, D., Cottrell, L., Griffin, R., Takami, A., Miyoshi, T., Hatakeyama, S., Shimono, A., Sun, J. Y., Zhang, Y. M., Dzepina, K., Kimmel, J. R., Sueper, D., Jayne, J. T., Herndon, S. C., Trimborn, A. M., Williams, L. R., Wood, E. C., Middlebrook, A. M., Kolb, C. E., Baltensperger, U., and Worsnop, D. R.: Evolution of organic aerosols in the atmosphere, Science, 326, 1525-1529, 2009.

Jo, D. S., Park, R. J., Kim, M. J., and Spracklen, D. V.: Effects of chemical aging on global secondary organic aerosol using the volatility basis set approach, Atmos. Environ., 81, 230-244, 2013.

Jöckel, P., Sander, R., Kerkweg, A., Tost, H., and Lelieveld, J.: Technical Note: The Modular Earth Submodel System (MESSy) - a new approach towards Earth System Modeling, Atmos. Chem. Phys., 5, 433-444, doi:10.5194/acp-5-433-2005, 2005.

Jöckel, P., Tost, H., Pozzer, A., Brühl, C., Buchholz, J., Ganzeveld, L., Hoor, P., Kerkweg, A., Lawrence, M. G., Sander, R., Steil, B., Stiller, G., Tanarhte, M., Taraborrelli, D., van Aardenne, J., and Lelieveld, J.: The atmospheric chemistry general circulation model ECHAM5/MESSy1: consistent simulation of ozone from the surface to the mesosphere, Atmos. Chem. Phys., 6, 50675104, doi:10.5194/acp-6-5067-2006, 2006.

Jöckel, P., Kerkweg, A., Pozzer, A., Sander, R., Tost, H., Riede, H., Baumgaertner, A., Gromov, S., and Kern, B.: Development cycle 2 of the Modular Earth Submodel System (MESSy2), Geosci. Model Dev., 3, 717-752, doi:10.5194/gmd-3-717-2010, 2010.

Kanakidou, M., Seinfeld, J. H., Pandis, S. N., Barnes, I., Dentener, F. J., Facchini, M. C., Van Dingenen, R., Ervens, B., Nenes, A., Nielsen, C. J., Swietlicki, E., Putaud, J. P., Balkanski, Y., Fuzzi, S., Horth, J., Moortgat, G. K., Winterhalter, R., Myhre, C. E. L., Tsigaridis, K., Vignati, E., Stephanou, E. G., and Wilson, J.: Organic aerosol and global climate modelling: a review, Atmos. Chem. Phys., 5, 1053-1123, doi:10.5194/acp-5-1053-2005, 2005.

Karl, M., Tsigaridis, K., Vignati, E., and Dentener, F.: Formation of secondary organic aerosol from isoprene oxidation over Europe, Atmos. Chem. Phys., 9, 7003-7030, doi:10.5194/acp-97003-2009, 2009.

Kerkweg, A., Buchholz, J., Ganzeveld, L., Pozzer, A., Tost, H., and Jöckel, P.: Technical Note: An implementation of the dry removal processes DRY DEPosition and SEDImentation in the Modular Earth Submodel System (MESSy), Atmos. Chem. Phys., 6, 4617-4632, doi:10.5194/acp-6-4617-2006, 2006a.

Kerkweg, A., Sander, R., Tost, H., and Jöckel, P.: Technical note: Implementation of prescribed (OFFLEM), calculated (ON-
LEM), and pseudo-emissions (TNUDGE) of chemical species in the Modular Earth Submodel System (MESSy), Atmos. Chem. Phys., 6, 3603-3609, doi:10.5194/acp-6-3603-2006, 2006 b.

Kroll, J. H. and Seinfeld, J. H.: Chemistry of secondary organic aerosol: Formation and evolution of low-volatility organics in the atmosphere, Atmos. Environ., 42, 3593-3624, 2008.

Lane, T. E., Donahue, N. M., and Pandis, S. N.: Simulating secondary organic aerosol formation using the volatility basis-set approach in a chemical transport model, Atmos. Environ., 42, 7439-7451, 2008.

Lauer, A., Eyring, V., Hendricks, J., Jöckel, P., and Lohmann, U.: Global model simulations of the impact of ocean-going ships on aerosols, clouds, and the radiation budget, Atmos. Chem. Phys., 7, 5061-5079, doi:10.5194/acp-7-5061-2007, 2007.

Lee, L. A., Pringle, K. J., Reddington, C. L., Mann, G. W., Stier, P., Spracklen, D. V., Pierce, J. R., and Carslaw, K. S.: The magnitude and causes of uncertainty in global model simulations of cloud condensation nuclei, Atmos. Chem. Phys., 13, 8879-8914, doi:10.5194/acp-13-8879-2013, 2013.

Lipsky, E. M. and Robinson, A. L.: Effects of dilution on fine particle mass and partitioning of semivolatile organics in diesel exhaust and wood smoke, Environ. Sci. Technol., 40, 155-162, 2006.

Lohmann, U., Stier, P., Hoose, C., Ferrachat, S., Kloster, S., Roeckner, E., and Zhang, J.: Cloud microphysics and aerosol indirect effects in the global climate model ECHAM5-HAM, Atmos. Chem. Phys., 7, 3425-3446, doi:10.5194/acp-7-3425-2007, 2007.

May, A. A., Saleh, R., Hennigan, C. J., Donahue, N. M., and Robinson, A. L.: Volatility of organic molecular markers used for source apportionment analysis: measurements and implications for atmospheric lifetime, Environ. Sci. Technol., 46, 1243512444, 2012.

Miracolo, M. A., Hennigan, C. J., Ranjan, M., Nguyen, N. T., Gordon, T. D., Lipsky, E. M., Presto, A. A., Donahue, N. M., and Robinson, A. L.: Secondary aerosol formation from photochemical aging of aircraft exhaust in a smog chamber, Atmos. Chem. Phys., 11, 4135-4147, doi:10.5194/acp-11-4135-2011, 2011

Morgan, W. T., Allan, J. D., Bower, K. N., Highwood, E. J., Liu, D., McMeeking, G. R., Northway, M. J., Williams, P. I., Krejci, R., and Coe, H.: Airborne measurements of the spatial distribution of aerosol chemical composition across Europe and evolution of the organic fraction, Atmos. Chem. Phys., 10, 4065-4083, doi:10.5194/acp-10-4065-2010, 2010.

Murphy, B. N. and Pandis, S. N.: Simulating the formation of semivolatile primary and secondary organic aerosol in a regional chemical transport model, Environ. Sci. Technol., 43, 47224728, 2009.

Murphy, B. N., Donahue, N. M., Fountoukis, C., Dall'Osto, M., O'Dowd, C., Kiendler-Scharr, A., and Pandis, S. N.: Functionalization and fragmentation during ambient organic aerosol aging: application of the 2-D volatility basis set to field studies, Atmos. Chem. Phys., 12, 10797-10816, doi:10.5194/acp-1210797-2012, 2012.

Murphy, B. N., Donahue, N. M., Robinson, A. L., and Pandis, S. N.: A naming convention for atmospheric organic aerosol, Atmos. Chem. Phys., 14, 5825-5839, doi:10.5194/acp-14-58252014, 2014. 
Ng, N. L., Kroll, J. H., Keywood, M. D., Bahreini, R., Varutbangkul, V., Flagan, R. C., Seinfeld, J. H., Lee, A., and Goldstein, A. H.: Contribution of first- versus second-generation products to secondary organic aerosols formed in the oxidation of biogenic hydrocarbons, Environ. Sci. Technol., 40, 2283-2297, 2006.

Pandis, S. N., Wexler, A. S., and Seinfeld, J. H.: Secondary organic aerosol formation and transport. 2. Predicting the ambient secondary organic aerosol-size distribution, Atmos. Environ. AGen., 27, 2403-2416, 1993.

Pandis, S. N., Donahue, N. M., Murphy, B. N., Riipinen, I., Fountoukis, C., Karnezi, E., Patoulias, D., and Skyllakou, K.: Introductory lecture: Atmospheric organic aerosols: insights from the combination of measurements and chemical transport models, Faraday Discuss., 165, 9-24, doi:10.1039/c3fd00108c, 2013.

Pathak, R. K., Presto, A. A., Lane, T. E., Stanier, C. O., Donahue, N. M., and Pandis, S. N.: Ozonolysis of ?-pinene: parameterization of secondary organic aerosol mass fraction, Atmos. Chem. Phys., 7, 3811-3821, doi:10.5194/acp-7-3811-2007, 2007.

Pöschl, U., von Kuhlmann, R., Poisson, N., and Crutzen, P. J.: Development and intercomparison of condensed isoprene oxidation mechanisms for global atmospheric modeling, J. Atmos. Chem., 37, 29-52, 2000.

Pozzer, A., Jöckel, P., Sander, R., Williams, J., Ganzeveld, L., and Lelieveld, J.: Technical Note: The MESSy-submodel AIRSEA calculating the air-sea exchange of chemical species, Atmos. Chem. Phys., 6, 5435-5444, doi:10.5194/acp-6-5435-2006, 2006.

Pozzer, A., de Meij, A., Pringle, K. J., Tost, H., Doering, U. M., van Aardenne, J., and Lelieveld, J.: Distributions and regional budgets of aerosols and their precursors simulated with the EMAC chemistry-climate model, Atmos. Chem. Phys., 12, 961-987, doi:10.5194/acp-12-961-2012, 2012.

Pringle, K. J., Tost, H., Message, S., Steil, B., Giannadaki, D., Nenes, A., Fountoukis, C., Stier, P., Vignati, E., and Lelieveld, J.: Description and evaluation of GMXe: a new aerosol submodel for global simulations (v1), Geosci. Model Dev., 3, 391-412, doi:10.5194/gmd-3-391-2010, 2010.

Pugh, T. A. M., MacKenzie, A. R., Hewitt, C. N., Langford, B., Edwards, P. M., Furneaux, K. L., Heard, D. E., Hopkins, J. R., Jones, C. E., Karunaharan, A., Lee, J., Mills, G., Misztal, P., Moller, S., Monks, P. S., and Whalley, L. K.: Simulating atmospheric composition over a South-East Asian tropical rainforest: performance of a chemistry box model, Atmos. Chem. Phys., 10, 279-298, doi:10.5194/acp-10-279-2010, 2010.

Pye, H. O. T. and Seinfeld, J. H.: A global perspective on aerosol from low-volatility organic compounds, Atmos. Chem. Phys., 10, 4377-4401, doi:10.5194/acp-10-4377-2010, 2010.

Robinson, A. L., Donahue, N. M., Shrivastava, M. K., Weitkamp, E. A., Sage, A. M., Grieshop, A. P., Lane, T. E., Pierce, J. R., and Pandis, S. N.: Rethinking organic aerosols: Semivolatile emissions and photochemical aging, Science, 315, 1259-1262, 2007.

Robinson, A. L., Grieshop, A. P., Donahue, N. M., and Hunt, S. W.: Updating the conceptual model for fine particle mass emissions from combustion systems, J. Air Waste Manage., 60, 1204-1222, 2010.

Röckner, E., Brokopf, R., Esch, M., Giorgetta, M., Hagemann, S., Kornblueh, L., Manzini, E., Schlese, U., and Schulzweida, U.: Sensitivity of simulated climate to horizontal and vertical reso- lution in the ECHAM5 atmosphere model, J. Climate, 19, 37713791, 2006.

Sander, R., Baumgaertner, A., Gromov, S., Harder, H., Jöckel, P., Kerkweg, A., Kubistin, D., Regelin, E., Riede, H., Sandu, A., Taraborrelli, D., Tost, H., and Xie, Z.-Q.: The atmospheric chemistry box model CAABA/MECCA-3.0, Geosci. Model Dev., 4, 373-380, doi:10.5194/gmd-4-373-2011, 2011.

Schauer, J. J., Kleeman, M. J., Cass, G. R., and Simoneit, B. R. T.: Measurement of emissions from air pollution sources. 2. C1 through C-30 organic compounds from medium duty diesel trucks, Environ. Sci. Technol., 33, 1578-1587, 1999.

Schauer, J. J., Kleeman, M. J., Cass, G. R., and Simoneit, B. R. T.: Measurement of emissions from air pollution sources. 3. C1-C-29 organic compounds from fireplace combustion of wood, Environ. Sci. Technol., 35, 1716-1728, 2001.

Schauer, J. J., Kleeman, M. J., Cass, G. R., and Simoneit, B. R. T.: Measurement of emissions from air pollution sources. 5. C-1-C32 organic compounds from gasoline-powered motor vehicles, Environ. Sci. Technol., 36, 1169-1180, 2002.

Schwartz, R. E., Russell, L. M., Sjostedt, S. J., Vlasenko, A., Slowik, J. G., Abbatt, J. P. D., Macdonald, A. M., Li, S. M., Liggio, J., Toom-Sauntry, D., and Leaitch, W. R.: Biogenic oxidized organic functional groups in aerosol particles from a mountain forest site and their similarities to laboratory chamber products, Atmos. Chem. Phys., 10, 5075-5088, doi:10.5194/acp-10-50752010, 2010.

Shrivastava, M., Fast, J., Easter, R., Gustafson Jr., W. I., Zaveri, R. A., Jimenez, J. L., Saide, P., and Hodzic, A.: Modeling organic aerosols in a megacity: comparison of simple and complex representations of the volatility basis set approach, Atmos. Chem Phys., 11, 6639-6662, doi:10.5194/acp-11-6639-2011, 2011.

Shrivastava, M. K., Lane, T. E., Donahue, N. M., Pandis, S. N., and Robinson, A. L.: Effects of gas particle partitioning and aging of primary emissions on urban and regional organic aerosol concentrations, J. Geophys. Res.-Atmos., 113, D18301, doi:10.1029/2007jd009735, 2008.

Spracklen, D. V., Jimenez, J. L., Carslaw, K. S., Worsnop, D. R., Evans, M. J., Mann, G. W., Zhang, Q., Canagaratna, M. R., Allan, J., Coe, H., McFiggans, G., Rap, A., and Forster, P.: Aerosol mass spectrometer constraint on the global secondary organic aerosol budget, Atmos. Chem. Phys., 11, 12109-12136, doi:10.5194/acp-11-12109-2011, 2011.

Stanier, C. O., Donahue, N. M., and Pandis, S. N.: Parameterization of secondary organic aerosol mass fractions from smog chamber data, Atmos. Environ., 42, 2276-2299, 2008.

Strader, R., Lurmann, F., and Pandis, S. N.: Evaluation of secondary organic aerosol formation in winter, Atmos. Environ., 33, 48494863, 1999.

Takahama, S., Schwartz, R. E., Russell, L. M., Macdonald, A. M., Sharma, S., and Leaitch, W. R.: Organic functional groups in aerosol particles from burning and non-burning forest emissions at a high-elevation mountain site, Atmos. Chem. Phys., 11, 6367-6386, doi:10.5194/acp-11-6367-2011, 2011.

Tost, H., Jöckel, P., Kerkweg, A., Sander, R., and Lelieveld, J.: Technical note: A new comprehensive SCAVenging submodel for global atmospheric chemistry modelling, Atmos. Chem. Phys., 6, 565-574, doi:10.5194/acp-6-565-2006, 2006.

Tsimpidi, A. P., Karydis, V. A., and Pandis, S. N.: Response of fine particulate matter to emission changes of oxides of nitrogen and 
anthropogenic volatile organic compounds in the Eastern United States, J. Air Waste Manage., 58, 1463-1473, 2008.

Tsimpidi, A. P., Karydis, V. A., Zavala, M., Lei, W., Molina, L., Ulbrich, I. M., Jimenez, J. L., and Pandis, S. N.: Evaluation of the volatility basis-set approach for the simulation of organic aerosol formation in the Mexico City metropolitan area, Atmos. Chem. Phys., 10, 525-546, doi:10.5194/acp-10-525-2010, 2010.

Tsimpidi, A. P., Karydis, V. A., Zavala, M., Lei, W., Bei, N., Molina, L., and Pandis, S. N.: Sources and production of organic aerosol in Mexico City: insights from the combination of a chemical transport model (PMCAMx-2008) and measurements during MILAGRO, Atmos. Chem. Phys., 11, 5153-5168, doi:10.5194/acp11-5153-2011, 2011.

van der Werf, G. R., Randerson, J. T., Giglio, L., Collatz, G. J., Mu, M., Kasibhatla, P. S., Morton, D. C., DeFries, R. S., Jin, Y., and van Leeuwen, T. T.: Global fire emissions and the contribution of deforestation, savanna, forest, agricultural, and peat fires (19972009), Atmos. Chem. Phys., 10, 11707-11735, doi:10.5194/acp10-11707-2010, 2010.

Zhang, Q., Canagaratna, M. R., Jayne, J. T., Worsnop, D. R., and Jimenez, J. L.: Time- and size-resolved chemical composition of submicron particles in Pittsburgh: Implications for aerosol sources and processes, J. Geophys. Res.-Atmos., 110, D07s09, doi:10.1029/2004jd004649, 2005.
Zhang, Q., Jimenez, J. L., Canagaratna, M. R., Allan, J. D., Coe, H., Ulbrich, I., Alfarra, M. R., Takami, A., Middlebrook, A. M., Sun, Y. L., Dzepina, K., Dunlea, E., Docherty, K., DeCarlo, P. F., Salcedo, D., Onasch, T., Jayne, J. T., Miyoshi, T., Shimono, A., Hatakeyama, S., Takegawa, N., Kondo, Y., Schneider, J., Drewnick, F., Borrmann, S., Weimer, S., Demerjian, K., Williams, P., Bower, K., Bahreini, R., Cottrell, L., Griffin, R. J., Rautiainen, J., Sun, J. Y., Zhang, Y. M., and Worsnop, D. R.: Ubiquity and dominance of oxygenated species in organic aerosols in anthropogenically-influenced Northern Hemisphere midlatitudes, Geophys. Res. Lett., 34, L13801, doi:10.1029/2007g1029979, 2007.

Zhang, Q. J., Beekmann, M., Drewnick, F., Freutel, F., Schneider, J., Crippa, M., Prevot, A. S. H., Baltensperger, U., Poulain, L., Wiedensohler, A., Sciare, J., Gros, V., Borbon, A., Colomb, A., Michoud, V., Doussin, J.-F., Denier van der Gon, H. A. C., Haeffelin, M., Dupont, J.-C., Siour, G., Petetin, H., Bessagnet, B., Pandis, S. N., Hodzic, A., Sanchez, O., Honoré, C., and Perrussel, O.: Formation of organic aerosol in the Paris region during the MEGAPOLI summer campaign: evaluation of the volatilitybasis-set approach within the CHIMERE model, Atmos. Chem. Phys., 13, 5767-5790, doi:10.5194/acp-13-5767-2013, 2013. 